CUADERNOS DE ESTUDIOS GALLEGOS, LXIII Núm. 129 (enero-diciembre 2016), págs. 125-162

ISSN: $0210-847 \mathrm{X}$

DOI: $10.3989 /$ ceg.2016.129.04

\title{
OS SYNODI SUEVO-CATÓLICOS: IMPLICACIÓNS POLÍTICO-ADMINISTRATIVAS DUNHA BIPARTICIÓN METROPOLITANA
}

\author{
Martín Fernández CALO \\ Universidade de Santiago de Compostela
}

Copyright: (C) 2016 CSIC. Este es un artículo de acceso abierto distribuido bajo los términos de una licencia de uso y distribución Creative Commons Attribution (CC-by) España 3.0.

Cómo citar/Citation: Martín FernáNDEZ CALO, "Os «synodi» suevo-católicos: implicacións político-administrativas dunha bipartición metropolitana", Cuadernos de Estudios Gallegos, 63, núm. 129 (2016), págs. 125-162, DOI: http://dx.doi.org/10.3989/ceg.2016.129.04 


\section{OS SYNODI SUEVO-CATÓLICOS: IMPLICACIÓNS POLÍTICO-ADMINISTRATIVAS DUNHA BIPARTICIÓN METROPOLITANA}

Resumo

Como parte dun interese máis amplo por enxergar o ordenamento institucional galaico de época suevo-católica, o presente artigo analiza a senlleira institución dos synodi, dúas circunscricións que dividiron a provincia eclesiástica da Gallaecia na segunda metade do século VI. A través da documentación eclesiástica que os testemuña, amósase a súa correspondencia metropolitana. Incardínanse os synodi no seu contexto histórico, canda outras modificacións do ordenamento metropolitano en determinadas igrexas provinciais e rexionais, e demóstrase a constante influencia nelas dun determinante factor político. Sintetízase a valoración historiográfica dos synodi, que en grande medida eludiu este factor. Avaliando finalmente en fondura a súa influencia para o caso concreto dos synodi suevo-católicos, identifícanse múltiples implicacións político-administrativas subxacentes nos mesmos.

Palabras Clave: Tardoantigüidade, Gallaecia, período suevo-católico, metrópole eclesiástica, bipartición metropolitana.

\section{LOS SYNODI SUEVO-CATÓLICOS: IMPLICACIONES POLÍTICO-ADMINISTRATIVAS DE UNA BIPARTICIÓN METROPOLITANA}

\section{RESUMEN}

Como parte de un interés más amplio por reconocer la ordenación institucional galaica de época suevo-católica, el presente artículo analiza la singular institución de los synodi, dos circunscripciones que dividieron la provincia eclesiática de la Gallaecia durante la segunda mitad del siglo VI. A través de la documentación eclesiástica que los atestigua, se muestra su correspondencia metropolitana. Se incardinan los synodi en su contexto histórico, junto con otras modificaciones de la articulación metropolitana en determinadas iglesias provinciales y regionales, y se demuestra la constante influencia en ellas de un determinante factor político. Se sintetiza la valoración historiográfica de los synodi, que ha eludido en gran medida este factor. Evaluando finalmente en profundidad su influencia para el caso concreto de los synodi suevo-católicos, se identifican múltiples implicaciones político-administrativas subyacentes en los mismos.

Palabras clave: Tardoantigüedad, Gallaecia, período suevo-católico, metrópoli eclesiástica, bipartición metropolitana.

\section{SUEVE CATHOLIC SYNODI: POLITICAL-ADMINISTRATIVE IMPLICATIONS OF A METROPOLITAN BIPARTITION}

\section{ABSTRACT}

This paper analyzes, as part of a broader aim of recognizing the Gallaecian institutional ordination during the Sueve Catholic period, the unique institution of synodi, two districts which divided the ecclesiastical province of Gallaecia in the second half of the $6^{\text {th }}$ century. Their metropolitan correspondence is shown throughout the involved ecclesiastical documentation. Then synodi are located in their historical context, along with other modifications on metropolitan articulation of certain provincial and regional churches, which demonstrates the constant influence of a determinant political factor on them. The historiographical assessment of Gallaecian synodi, which has largely evaded this factor, is summarized. At last, its influence in the concrete case of Sueve Catholic synodi is evaluated in depth, identifying on them multiple political and administrative implications.

KEY words: Late Antiquity, Gallaecia, Sueve Catholic period, ecclesiastical metropolis, metropolitan bipartition. 
Recibido/Received: 14/03/2016

Aceptado/Accepted: 18/05/2016

política e a administración do Reino Suevo da Gallaecia conforman un
eido historiográfico pouco fructífero por mor da notábel ausencia de datos
positivos, determinada fundamentalmente por non se teren conservado as súas fontes lexislativas. Nestas circunstancias, como recentemente defendín na miña tese de licenciatura, a documentación eclesiástica supón unha alternativa cuxas implicacións político-administrativas cómpre valorarmos en fondura ${ }^{1}$.

Neste senso, o propósito do presente artigo é a análise exhaustiva dunha das máis significativas manifestacións institucionais da Igrexa galaica deste período: o synodus. O presente estudo propón valorar as implicacións que os synodi reportan sobre o poder temporal suevo; e, en contrapartida, a potencial influencia que a territorialidade política exerceu sobre a eclesiástica na Gallaecia deste tempo. Non é este un vieiro moi explorado pola historiografía: os synodi pasan case desapercibidos nos estudos da Gallaecia sueva, malia conformaren, como se amosará, unha das súas principais innovacións eclesiásticas e teren un amplo, embora desdebuxado, transfondo político.

A prol do rigor analítico, o presente estudo trata individualizadamente, en sucesivas seccións, as diversas cuestións implicadas na resolución do antedito propósito xeral. Comézase analizando en fondura a propia institución do synodus, para a que semella existir unha significativa evidencia a prol da súa lectura como bipartición da potestas metropolitana galaica, e xa que logo, da súa equiparación a provincias eclesiásticas $(\S 1)$. De seguido, amósanse os factores internos e extra-políticos da Igrexa galaica que condicionaron a súa creación, e que acapararon case toda a atención da historiografía moderna (\$2). Co gallo de amosar a conveniencia de valorarmos tamén un factor político, externo á Igrexa, analízase sumariamente o contexto eclesiástico global, onde se produciron varias innovacións metropolitanas análogas na Tardoantigüidade. Os casos escolleitos, nos que é indisociábel a influencia do poder político, son os máis achegados aos

\footnotetext{
1 Martín Fernández Calo, A organización político-administrativa de Galicia na Antigüidade: séculos II a.C. - VIII d.C., Santiago de Compostela, Universidade de Santiago de Compostela (tese de licenciatura), 2015, páxs. 115-120.
} 
synodi suevo-católicos: os antecedentes baixo-romanos (§3), a reformulación coetánea da provincia Carthaginensis (§4), e a algo posterior bipartición metropolitana anglo-saxona ( $(5)$. Asumida a conveniencia de identificarmos tamén no caso galaico-suevo tal influencia, estúdanse as súas implicacións xerais (§6) e as especificamente asociadas á territorialidade eclesiástica sancionada cos synodi (§7). Nas conclusións, finalmente, pondéranse os resultados acadados.

\section{ENTENDENDO OS SYNODI E A SÚA CORRESPONDENCIA METROPOLITANA}

Como se vén de aludir, a innovación institucional máis orixinal da Igrexa galaica baixo o dominio suevo-católico foi o synodus: cada unha das dúas circunscricións que dividiron pola metade a xurisdición eclesiástica global do Reino $^{2}$. Por medio desta institución, todas as igrexas episcopais arrombáronse entre a dependencia eclesiástica dos prelados de Braga e Lugo, tal e como se recolle na táboa 1:

Táboa 1. Os synodi suevo-católicos.

\begin{tabular}{|c|c|}
\hline Synodus de Braga & id., de Lugo \\
\hline Coimbra & Astorga \\
Dume & Bretoña \\
Idanha & Iria \\
Lamego & Ourense \\
Porto & Tui \\
Viseu & \\
\hline
\end{tabular}

Sen dúbida, os synodi instauráronse despois do primeiro concilio de Braga, en cuxas actas non se mencionan, e antes do segundo, cando xa aparecen constituídos. O comezo da súa andaina histórica acótase, xa que logo, entre o 561 e o 572. Pola súa banda, un documento eclesiástico, o "discurso de Teodomiro", atribúeos a un terceiro concilio, supostamente reunido en Lugo no 569, que como se percibe encadrela coa acotación antedita.

Con todo, a veracidade deste documento, e dentro del, especificamente, a noción do devandito concilio de Lugo, xa foi obxecto da suspicacia filolóxica do padre Enrique Flórez ${ }^{3}$, cuxos argumentos non foron en absoluto concluíntes ${ }^{4}$.

\footnotetext{
2 Ibíd., páx. 117.

3 Enrique Flórez, España Sagrada, t. IV, Madrid, Real Academia de la Historia, 1839, páxs. 130 e seguintes.

4 Buenaventura CañIzares del Rey, “Concilios Lucenses”, Lucensia, 34 (2007).
} 
Pierre David, alén de rehabilitar decisivamente o Parroquial Suevo, asociado á mesma documentación, culminaría a tendencia iniciada polo anterior, reiterando algúns dos seus argumentos e atribuíndo o discurso de Teodomiro a unha suposta interpolación medieval, promovida por algún falsario crego lucense interesado en asignar á súa igrexa unha pretérita dignidade metropolitana que nunca tería acadado na realidade ${ }^{5}$. Axiña se amosará que esta última noción se afasta da realidade documental, pois o discurso de Teodomiro non é o único testemuño explícito da condición metropolitana do Lugo suevo-católico. Porén, dende isto, a comunidade académica adoita eludir, máis do que desbotar explicitamente, a noción do concilio de Lugo do 569, e consecuentemente tamén a do seu suposto discurso de apertura ${ }^{6}$. Os limitados obxectivos do presente estudo obrigan a eludirmos, unha vez máis, esta importante cuestión. Por esta razón, o discurso de Teodomiro será citado cando proceda polas súas implicacións potenciais, mais sen desatendermos nunca a controversia filolóxica e historiográfica que o arrodea; pois, como ben sinala Jorge de Alarcão, o seu carácter apócrifo... não exclui a possibilidade (ou probabilidade) de ser substancialmente verdadeira a notícia que nele se contém ${ }^{7}$.

Os synodi son orixinais tanto verbo á súa denominación -que habitualmente designa unha reunión conciliar física, non unha circunscrición eclesiástica-, como verbo ao ordenamento eclesiástico que constatan. Mais non o son a nivel competencial: o synodus é, perante todo, unha xurisdición de potestas metropolitana. Isto faino corresponder ao que comunmente se denomina "provincia eclesiástica". A documentación, con todo, matiza tan doada correspondencia ${ }^{8}$ :

Quum Gallaeciae prouinciae episcopi tam ex Bracarensi quam ex Lucensi synodo cum suis metropolitanis praefati regis [Mironis] simul in metropolitana Bracarensi ecclesia conuenissent.

\footnotetext{
5 Pierre DAVID, Études historiques sur la Galice et le Portugal du VIe au XII e siècle, Lisboa-Paris, Portugalia-Les Belles Lettres, 1947, páxs. 65-66.

6 Arredor do estado da cuestión, véxase José Miguel Novo Güisán, "Lugo en los tiempos oscuros: las menciones literarias de la ciudad entre los siglos V y X (3)", Boletín do museo provincial de Lugo, 8, 2 (1997-1998), páxs. 183-185. Cómpre citarmos, como salientábel excepción, a Abilio BARBERO, "Las divisiones eclesiásticas y las relaciones entre la iglesia y el Estado en la España de los siglos VI y VII", en A. Barbero, La sociedad visigoda y su entorno histórico, Madrid, Siglo XXI, 1992, páxs. 183 e seguintes, quen argumenta que o contido do discurso de Teodomiro non se afasta das normas e usos eclesiásticos do seu -pretendido- contexto histórico.

7 Jorge de Alarcão, "Os limites das dioceses suevas de Bracara e de Portucale", Portugalia, 36 (2015), páx. 36.

8 Concilium Bracarensis II, praefatio.
} 
O texto reproducido é un fragmento inicial do prefacio das actas do segundo concilio de Braga, do 572, onde se explicita o ámbito xeográfico abranguido polos bispos participantes. Neste senso, a procedencia global dos mesmos é a prouincia Gallaecia, sen dúbida a correspondencia eclesiástica da xurisdición civil global do Reino9: o regnum Sueuorum ${ }^{10}$ ou Galliciense regnum ${ }^{11}$.

Embaixo desta provincia eclesiástica, pola contra, o texto reproducido concreta a división interna da mesma entre os synodi de Braga e Lugo. O plural de ablativo cum suis metropolitanis, impón que cada un dos mesmos estivese representado por cadanseu bispo metropolitano. De feito, os bispos de Braga e Lugo asinarían estas mesmas actas conciliares como metropolitanos de cadansúa igrexa ${ }^{12}$ :

Martinus Bracarensis metropolitanae ecclesiae episcopus, his gestis subscripsi [...]. Item, ex synodo Lucensi. Nitigius Lucensis metropolitanae ecclesiae episcopus, his gestis subscripsi.

Pola súa banda, atopamos un indicio complementario da bipartición eclesiástica no "Parroquial Suevo". Este documento é unha listaxe de natureza eclesiástica redactada dun xeito inequívoco entre os anos 572 e $589^{13}$, presumibelmente para fixar as xurisdicións episcopais da Igrexa galaica. O Parroquial foi obxecto da mesma controversia filolóxica có discurso de Teodomiro ${ }^{14}$, pois case todas as súas compilacións documentais están precisamente introducidas por estoutro texto. A edición de Pierre David ${ }^{15}$ separou definitivamente a valoración filolóxica do discurso da do Parroquial, confirmando a historicidade e datación tardo-antiga deste, e presumindo aquel froito dunha interpolación medieval, segundo xa se mencionou

\footnotetext{
9 Avelino de Jesus da Costa, O bispo D. Pedro e a organização da arquidiocese de Braga, vol. I, Braga, Irmandade de S. Bento da Porta Aberta, 1997, páx. 41.

${ }^{10}$ Hidacio de Chaves, Chronicon, 71 [63]; 119 [111]; 122 [114]; 137 [129]; 172 [165]; 230 [226]; 237 [233]; 240 [236]; Xoán de Bíclaro, Chronicon, Iustinus, IV, 4; VI, 3; X, 3; Mauritius, I, 1; II, 2; Isidoro de Sevilla, Historia de regibus Gothorum, Vandalorum et Suevorum, 91-92.

${ }_{11}$ Gregorio de Tours, Historia Francorum, VI, 43. Arredor da mudanza de nomenclatura do Reino Suevo no período católico verbo ao ariano, véxase Pablo de la Cruz DíAz Martínez, "Gallaecia: de Reino Suevo a provincia visigoda", en Gerardo Pereira Menaut, Galicia fai dous mil anos: o feito diferencial galego, vol. I, Santiago de Compostela, Museo do Pobo Galego, 1997, páx. 259; P. C. Díaz Martínez, "La Hispania Visigoda (257-611)", en P. C. Díaz Martínez, Celia Martínez Maza e Francisco Javier Sanz Huesma, Hispania tardoantigua y visigoda, Madrid, Istmo, 2007, páx. 371; Anselmo López Carreira, O reino medieval de Galicia: contribución a unha historia política, Vigo, A Nosa Terra, 2008, páx. 78; P. C. Díaz Martínez, El Reino suevo (411-585), Madrid, Akal, 2011; M. Fernández Calo, A organización..., páx. 111.

${ }_{12}$ Conc. Brac. II, subscriptiones.

13 P. DAvid, Études..., páxs. 67-68.

14 E. Flórez, España Sagrada, t. IV, páxs. 130 e seguintes.

15 P. David, Études..., páxs. 31-44.
} 
con anterioridade. Dende isto, a xeneralidade da comunidade académica asume a historicidade e excepcionalidade do Parroquial Suevo, e rexeita-ou simplemente, como xa se avanzou, elude- a do discurso de Teodomiro que o introduce.

O indicio co que o Parroquial Suevo complementa a noción da bipartición eclesiástica suevo-católica é a súa orde de redacción: a listaxe comeza por Braga ${ }^{16}$, continúa polas igrexas de Porto, Lamego, Coimbra, Viseu, Dume e Idanha ${ }^{17}$; e remata por Lugo ${ }^{18}$, Ourense, Astorga, Iria, Tui e Bretoña ${ }^{19}$. A orde de mención reproduce con exactitude, xa que logo, a xerarquía eclesiástica dos synodi: Braga, synodus de Braga, Lugo, synodus de Lugo ${ }^{20}$. Ademais, tal estrutura relacional correspóndese exactamente coa reproducida no segundo concilio de Braga, cuxas actas asinou de primeiro o metropolitano bracarense, seguíndolle todos os seus sufragáneos, e só entón, baixo a fórmula "ex synodo Lucensi", o metropolitano lucense e os seus senllos sufragáneos ${ }^{21}$. A nidia analoxía da estrutura relacional entrambos os documentos sintetízase na táboa 2 :

Táboa 2. Orde de mención episcopal no parroquial Suevo e no segundo concilio de Braga.

\begin{tabular}{|c|c|}
\hline Parroquial Suevo & Concilio II de Braga \\
\hline BRAGA & BRAGA \\
Porto & Viseu \\
Lamego & Coimbra \\
Coimbra & Idanha \\
Viseu & Lamego \\
Dumio & Meinedo \\
Idanha & LUG0 \\
LUG0 & Iria \\
Ourense & Ourense \\
Astorga & Astorga \\
Iria & Tui \\
Tui & Bretoña \\
Bretoña & \\
\hline
\end{tabular}

\footnotetext{
16 Parochiale Suevum, I.

17 Ibíd., II-VII.

18 Ibíd., VIII.

19 Ibíd., IX-XIII.

20 Cfr. táboa 1.

21 Conc. Brac. II, subs.
} 
Cómpre presumirmos, pois, que a estrutura común das listaxes episcopais reproducidas en ambos os documentos deberíase ao idéntico contexto eclesiástico no que foron redactados. A estrutura da listaxe episcopal do Parroquial Suevo sería, neste senso, un reflexo da vixencia dos synodi e da superior dignidade das igrexas de Braga e Lugo verbo ás súas sufragáneas, cuxa mención se arromba entre elas. O Parroquial, se per se non menciona os synodi nin a condición metropolitana de Braga e Lugo, si constitúe, xunguido ás actas do segundo concilio de Braga, un indicio complementario para o testemuño dunha mesma realidade eclesiástica.

Por último, o discurso de Teodomiro, cuxa problemática vén de referirse, non menciona nada dos synodi como xurisdición eclesiástica, mais si da bipartición metropolitana que se tería definido no -tamén controvertido- concilio de Lugo do $569^{22}$ :

Dum hanc [Theodemiri] epistolam episcopi legerunt, elegerunt in synodo, ut sedes Lucensis esset metropolitana, sicut et Bracara.

En suma, a evidencia documental, inclúase nela ou non o controvertido discurso de Teodomiro, converte de certo ao synodus en virtualmente sinónimo de "provincia eclesiástica". Aparentemente, tal correspondencia contradí a mención primeira da prouincia Gallaecia nas actas do segundo concilio de Braga como territorialidade eclesiástica global do Reino. Por iso, esta mención debe de tratarse dunha referencia simplemente coronímica ao espazo xurisdicional global da Igrexa galaica, sen correspondencia institucional ningunha; e do mesmo xeito sen ningún cargo eclesiástico asociado a ela. Se cadra os synodi terían adoptado tal denominación pola vixencia do termo, semanticamente coronímico e non administrativo, da prouincia Gallaecia.

Independentemente desta cuestión, a dignidade metropolitana dos prelados representantes de cada synodus colíxese das explícitas referencias documentais amosadas, amais dos non menos significativos indicios que redundan na mesma conclusión. Deste xeito, determinaríase que os bispos de Braga e Lugo compartiron a potestas e a xurisdición metropolitana da Igrexa galaica durante o período suevo-católico.

Con todo, o xa mencionado Pierre David obstou esta aparente evidencia documental, centrando a súa crítica no discurso de Teodomiro, que se trataría dunha falsificación posterior, fabriquée par un clerc de Lugo, destinada a lexitimar a influencia da súa igrexa na Gallaecia alto-medieval ${ }^{23}$. Esta percepción callou na

\footnotetext{
22 Par. Suev., praef.

23 P. DAvid, Études..., páxs. 65-67.
} 
historiografía da Igrexa galego-portuguesa -como, de feito, non podía ser menos vindo dun dos seus meirandes estudosos ${ }^{-24}$, pero non se corresponde co contido dos textos orixinais. En efecto, aínda desbotando toda historicidade do discurso de Teodomiro, ficaría a evidencia das actas do segundo concilio de Braga, sobre as que non pesa sospeita ningunha de falsificación. Contra a opinión de Pierre David, o bispo metropolitano san Martiño de Braga non est seul à prendre ce titre ${ }^{25}$ nas subscricións das devanditas actas, senón que, como se reproduciu, tamén asina en calidade de metropolitano o seu colega Nitixio de Lugo ${ }^{26}$.

Cómpre respectarmos, xa que logo, a noción imposta pola evidencia documental de que no período suevo-católico, independientemente de la autenticidad del concilio de Lugo $^{27}$, e canda menos no intre de celebración do segundo de Braga no 572, tanto o bispo desta cidade coma o de Lugo compartiron indefectibelmente a dignidade metropolitana do Reino a través da bipartición eclesiástica definida nos dous $s y n o d i^{28}$.

${ }^{24}$ Véxanse, por exemplo, J. A. da Costa, O bispo..., páx. 42; José Carbajal Sobral, Los concilios de Braga en los siglos VI y VII, reflejo de la vida en la Gallaecia de la época, Porriño, 1999, páx. 218; Manuel Cecilio Díaz e Daría Vilariño Pintos, "La diócesis de Tuy hasta 1100", en José García Oro, Historia de las Diócesis Españolas, t. 14, Madrid, Biblioteca de autores cristianos, 2002, páx. 541.

25 P. DAvid, Études..., páx. 65.

${ }^{26}$ Véxase arriba a reprodución das subscricións do segundo concilio de Braga; cfr. Conc. Brac. II, praef.; subs.

27 P. C. Díaz Martínez, El reino..., páx. 230.

${ }^{28}$ Francisco María Ferrando y Arnau, Un concilio celebrado en Lugo el año 569: estudio histórico, Lugo, Juan María Bravo, 1893, páx. 28; Demetrio Mansilla Reollo, "Orígenes de la organización metropolitana en la Iglesia española”, Hispania Sacra, 12 (1959), páx. 277; Manuel Sotomayor y Muro, "La Iglesia de la España romana", en Ricardo García Villoslada, Historia de la Iglesia en España, t. I, Madrid, La Editorial Católica, 1979, páx. 397; P. C. DíAz MarTínez, "Gallaecia: de reino...", páx. 263; J. M. Novo GüIsÁN, "Lugo en los tiempos oscuros...", páx. 186; Franquelim Neiva SoAREs, "Os Concílios Suevos de Braga (561 e 572)”, en Erwin Koller e Hugo Laitenberger, Suevos-Schwaben: das Königreich der Sueben auf der Iberischen Halbinsel, 411585, Tübingen, Gunter Narr Verlag, 1998, páxs. 74-75; Purificación Ubric Rabaneda, La Iglesia y los Estados bárbaros en la Hispania del siglo V: 409-507, Universidad de Granada (tese de doutoramento), 2003, páx. 322; Julio Escalona Monge, "Patrones de fragmentación territorial: el fin del mundo romano en la Meseta del Duero", en Urbano Espinosa Ruíz e Santiago Castellanos García, Comunidades locales y dinámicas de poder en el norte de la Península Ibérica durante la Antigüedad Tardía, Logroño, Universidad de La Rioja, 2006, páx. 192; B. CañIZARES del Rey, "Concilios..."; A. López Carreira, O reino..., páx. 71; P. C. Díaz Martínez, El reino..., páxs. 193 e 229-230; Óscar NúÑEz García, Un novo deus para os galaicos: a cristianización de Gallaecia, Santiago de Compostela, Lóstrego, 2012, páx. 89; Rafael Barroso CABrera, Jorge Morín de PABlos e Isabel SÁnchez Ramos, "Gallaecia Gothica: de la conspiración del Dux Argimundus (589/590 d.C.) a la integración en el Reino visigodo de Toledo", Idanha-a-Velha, 1 (2015), páx. 74; M. FERNÁNDEZ CALO, A organización..., páx. 117. 


\section{FACTORES EXTRA-POLÍTICOS IMPLICADOS NA BIPARTICIÓN METROPOLITANA}

Dado que os synodi dividiron a xurisdición metropolitana da Igrexa galaica, a súa instauración constitúe unha acción política de grande calado; e a interpretación da mesma, un decisivo problema historiográfico referente á Gallaecia sueva. Cómpre identificarmos, para tal fin, os factores implicados na bipartición. De seguido desenvólvense os de natureza extra-política, que teñen protagonizado a súa valoración historiográfica.

A promoción metropolitana de Lugo, da que non existen precedentes, afecta de feito a toda a provincia eclesiástica. Obviamente, a bipartición provincial é lesiva para a potestas eclesiástica do bispo metropolitano afectado, neste caso o bracarense, que ve enaxenada a súa xurisdición previa. Neste senso, dificilmente o bispo de Braga promoveu a enaxenación da metade da súa provincia eclesiástica. Aplicarmos unha lóxica cui prodest para o factor interno -propiamente eclesiástico- deste feito, atoparía na súa beneficiaria absoluta, a igrexa episcopal de Lugo, o potencial factor promotor da creación dos synodi.

Con todo, embora esta cidade foi cabeza de conuentus iuridicus ${ }^{29}$ e mesmo probabelmente capital provincial da efémera provincia Hispania Superior no século $\mathrm{II}^{30}$, a súa igrexa non sobresaíu na Gallaecia baixo-romana, e de feito só hai constancia dela dende o ano 431, despois de asentados os bárbaros ${ }^{31}$. Este testemuño procede dunha noticia cronística que documenta ao bispo Agrestio de Lugo opoñéndose á ordenación episcopal doutros dous bispos, Pastor e Siagrio, de ubicación incerta ${ }^{32}$ :

In conuentu Lucensi, contra uoluntatem Agresti Lucensis episcopi, Pastor et Syagrius episcopi ordinantur.

Como se percibe, desta noticia non se desprende necesariamente o papel sobresaínte do bispo Agrestio dentro da súa provincia, e moito menos o da súa sé: estamos só perante un testemuño das disensións internas da Igrexa galaica do século V. Con todo, da relevante mención do devandito Agrestio especulouse a súa dignidade metropolitana. Neste caso, tal dignidade non se debería a unha

\footnotetext{
${ }^{29}$ Plinio o Vello, Naturalis Historia, III, 28.

${ }^{30}$ Géza Alföldy, Provincia Hispania Superior, A Coruña, Universidade da Coruña, 2002, páx. 60; José Miguel Novo Gürsán, "Lugo nos tempos escuros: as mencións literarias da cidade entre os séculos V e X (9)", Boletín do Museo Provincial de Lugo, 13 (2006-2008); Pablo Ozcáriz GiL, "Algunas consideraciones acerca de la provincia Hispania Superior y su administración", Pyrenae, 38, 2 (2007), páx. 37; M. Fernández Calo, A organización..., páx. 74.

31 M. Fernández Calo, A organización..., páx. 90.

${ }^{32}$ Hyd., Chron, 90 [102].
} 
primitiva bipartición da provincia eclesiástica nin á substitución de Braga como metrópole, senón a un arcaísmo eclesiástico incidente na Gallaecia deste tempo: a persistencia dunha valoración pre-nicena da xerarquía eclesiástica, que outorgaría a primacía simbólica da Igrexa aos seus bispos de máis antiga prelatura ${ }^{33}$. Semellante lectura é dende logo suxestiva e encadrela coa situación da Igrexa galaica, cuxa homologación ao cristianismo niceno, en termos de artellamento interno, foi moi serodia. De calquera xeito, deducirmos da lacónica noticia arriba reproducida a dignidade metropolitana do bispo Agrestio é, certamente, unha hipótese pouco consistente ${ }^{34}$.

Pola súa banda, o controvertido discurso de Teodomiro fornece, entre toda a documentación histórica dispoñíbel, a única explicación directa do factor interno da bipartición metropolitana: atribúea á "extensión" da provincia eclesiástica anterior, que abranguira todo o Reino, e ás disfuncións a ela asociadas. E faino dun xeito tan explícito, que case puidera respostar literalmente á nosa pregunta "por que se dividiu a provincia eclesiástica galaica?"35:

Quia in tota Gallaeciae regione, spatiosae satis dioeceses a paucis episcopis tenentur; ita ut aliquantae ecclesiae per singulos annos uix possint a suo episcopo uisitari. Insuper tantae prouinciae unus tantummodo metropolitanus episcopus est, et de extremis quibusque parochiis longum est singulis annis ad concilium conuenire.

Ou como resume Avelino de Jesus da Costa, a vastidão do território, que ia do Tejo ao mar Cantábrico, obrigou a dividir a metrópole bracarense ${ }^{36}$. Conforme ao texto reproducido, a extensión da provincia eclesiástica provocaba que os "poucos" bispos galaicos tivesen dificultades, primeiro, para visitaren anualmente todas as igrexas ao seu cargo; e, segundo, para asistiren aos concilios provinciais. Esta razón, estritamente interna da Igrexa galaica, levaríaa a promover novas sés episcopais e a instaurar os synodi que dividiron en dúas porcións a xurisdición metropolitana. Pierre David, que como xa se referiu obstaba o carácter metropolitano dos synodi e a fiabilidade do discurso de Teodomiro, supuxo isto une mesure

33 Demetrio Mansilla Reoyo, "Orígenes de la organización metropolitana en la Iglesia española", Hispania Sacra, 12 (1959), páx. 277. Paralelamente, Óscar NúÑEz GarCía, "Cristianismo, sociedad y poder: origen y evolución de la jerarquía eclesiástica en la Gallaecia antigua", Hispania Sacra, LXV, extra 2 (2013), páx. 18, amósase menos categórico e defende simplemente o papel protagonista do bispo de Lugo no seu conuentus.

${ }^{34}$ P. Ubric Rabaneda, La Iglesia..., páx. 323.

35 Par. Suev., praef.

36 A. J. da Costa, O bispo..., páx. 41. Insisten nesta mesma argumentación, por exemplo, D. MANSILLA Reoyo, “Orígenes...”, páx. 277; R. Barroso et al., "Gallaecia Gothica...”, páxs. 73-74. 
de décentralisation... destinée a rendre plus aisés les rapports hiérarchiques ${ }^{37}$, reproducindo pois a razón de fondo do antedito documento.

A provincia eclesiástica galaica era certamente extensa, pero isto dificilmente podería ter constituído o factor monocausal da súa bipartición. A Gallaecia sueva non era sequera máis extensa cá homónima baixo-romana, pois, embora se expandira polo sur a través de territorio anteriormente lusitano, perdera polo leste toda a súa xurisdición sobre a submeseta norte ${ }^{38}$. A distancia que separaba Braga, a metrópole, de Idanha, Bretoña ou Astorga, as sés máis excéntricas, era dabondo inferior á que separaba Calahorra de Tarragona, por citarmos un exemplo coetáneo; ou a Toledo romana de Cartaxena; ou mesmo o Lamego visigodo de Mérida, cando se restituíra, logo da desaparición do Reino Suevo, a provincia lusitana nos seus lindeiros baixo-romanos ${ }^{39}$. Por último, a distancia que separaba Braga da igrexa episcopal máis meridional, Idanha, non era significativamente inferior cá máis setentrional, Bretoña, ou a máis oriental, Astorga. E obviamente o prelado de Idanha mantivo as mesmas dificultades para asistir aos concilios provinciais logo da reforma, pois Braga, o synodus ao que foi adscrito, ficaba á mesma distancia da súa sé antes e despois da bipartición metropolitana. De feito, pouco despois da devandita bipartición tería máis dificultades para facelo, pois namentres o discurso de Teodomiro, supostamente lido no 569, menciona o concilio provincial anual (longum est singulis annis ad concilium conuenire) ${ }^{40}$, no segundo concilio de Braga, do 572, estipulouse, conforme á canonoloxía ecuménica, a reunión do concilio provincial dúas veces por ano ${ }^{41}$.

Cómpre, xa que logo, valorarmos outros factores implicados na bipartición metropolitana. Neste senso, Óscar Núñez García propuxo recentemente a presunta dualidad político-poblacional y religiosa entre o norte e o sur do Reino ${ }^{42}$. Esta razón fica lonxe de verse confirmada, e non só por ser aparentemente insuficiente para que unha Igrexa provincial formule interna e illadamente a súa bipartición, senón tamén porque non semella que tal dicotomía existise. É certo

\footnotetext{
${ }_{37}$ P. David, Études..., páxs. 65-66. Reproduce esta hipótese J. CArbajal Sobral, Los concilios..., páx. 218.

${ }^{38}$ Cfr. M. Fernández Calo, A organización..., páxs. 225-227, mapas 6-8.

39 Conc. Emeritensis, canon 8. Véxase, arredor desta cuestión, Amancio Isla Frez, La sociedad gallega en la Alta Edad Media, Madrid, Centro Superior de Investigaciones Científicas, 1992, páx. 6; J. Carbajal Sobral, Los concilios..., páxs. 211-212; A. López Carreira, O reino..., páxs. 97-101; P. C. Díaz Martínez, El reino..., páx. 249; R. Barroso et al., "Gallaecia Gothica...", páx. 75; M. Fernández Calo, A organización..., páxs. 147-149.

40 Véxase arriba a reprodución completa deste texto.

${ }^{41}$ Conc. Brac. II, capitula Martini, canon 18; cfr. Conc. Antiochenum, c. 20; Conc. Chalcedonensis, c. 19.

42 Óscar NúÑez García, “Cristianismo...”, páx. 26; defendido tamén en O. NúÑez García, Un novo deus..., páx. 90.
} 
que o Parroquial Suevo reporta que no norte da Gallaecia, e especialmente na sé iriense ${ }^{43}$, os topónimos de orixe etnonímica, aos que habitualmente se atribúe unha organización socio-política xentilicia remanescente ${ }^{44}$, son máis frecuentes do que no sur. Mais, en troques, as xurisdicións episcopais de Tui ou Ourense, sitas no synodus lucense, formaran parte do conuentus bracarense e das súas dinámicas socio-económicas dende época alto-romana. Do mesmo xeito, as igrexas luso-suevas tiveran esta mesma identificación excluínte previa, malia o que foron adscritas ao synodus bracarense canda outras igrexas da baixo-romana provincia Gallaecia, de diferente caracterización administrativa e socio-cultural. E, sobre todo, as sés de Braga, Porto e Tui, para as que o Parroquial Suevo asocia máis da metade do cómputo total de topónimos ${ }^{45}$, considéranse xeralmente un espazo xeográfico singularizado dentro do Reino, a súa área máis desenvolvida e sobre a que a monarquía exercería un control máis forte ${ }^{46}$, malia o que foron adscritas a synodi diferentes. Embora esta noción do fulcro centro-occidental do Reino estea probabelmente motivada por unha lectura reduccionista do Parroquial Suevo ${ }^{47}$, constátase que as notábeis diferenzas socio-culturais e diverxentes ritmos históricos detectados na amplietude da Gallaecia sueva non se corresponden, nin moito menos, coa nidia división latitudinal norte-sur plasmada nos synodi.

Insuficientes as hipóteses que se teñen ofrecido para explicar a bipartición metropolitana, cómpre centrarmos o exame histórico dos synodi suevo-católicos

\footnotetext{
43 Par. Suev., XI; cfr. nomeadamente os topónimos da interpolación (XI, 8).

44 Arredor dos topónimos "étnicos" do Parroquial Suevo, véxanse Fernando López AlsinA, La ciudad de Santiago de Compostela en la Alta Edad Media, Santiago de Compostela, Ayuntamiento de Santiago de Compostela, 1988, páx. 155; A. Isla Frez, La sociedad..., páxs. 10 e seguintes; P. C. Díaz Martínez, "Gallaecia, de reino...”, páx. 266; P. C. Díaz Martínez, "El Parrochiale Suevum: organización eclesiástica, poder político y poblamiento en la Gallaecia Tardoantigua”, en Jaime Alvar, Homenaje a José María Blázquez, vol. VI, Sevilla, Ediciones Clásicas, 1998, páx. 44; Juan Carlos Rivas Fernández, Antigüedad del episcopado auriense, Ourense, Duen de Bux, 2003, páxs. 126 e 265. O carácter xentilicio e singular destas entidades ten sido recentemente matizado por José Carlos SÁnchez PARDo, "Organización eclesiástica y social en la Galicia tardoantigua: una perspectiva geográfico-arqueológica del Parroquial Suevo”, Hispania Sacra, LXVI, 134 (2014), páxs. 461-464. 45 Par. Suev., I-II e XII.

46 P. DAvid, Études..., páxs. 80-82; Manuel Cecilio DíAz, "La cristianización en Galicia”, en Fernando Acuña Castroviejo et al., La romanización de Galicia, A Coruña, Castro, 1976, páx. 115; Casimiro Torres Rodríguez, El reino de los suevos, A Coruña, Barrié de la Maza, 1977; A. Isla Frez, La sociedad..., páx. 15; P. C. DíAz Martínez, "Gallaecia, de reino...”, páx. 263; P. C. Díaz Martínez, "El Parrochiale Suevum...”, páx. 41; Jorge LóPez Quiroga, El final de la Antigüedad en la Gallaecia: la transformación de las estructuras de poblamiento entre Miño y Duero, siglos V al X, A Coruña, Pedro Barrié de la Maza, 2004, páx. 48; P. C. Díaz Martínez, El reino..., páxs. 193 e 197; O. NúÑEz García, “Cristianismo...”, páxs. 26-27; J. C. SÁnchez PARdo, “Organización...”, páxs. 466 e seguintes. 47 M. Fernández Calo, A organización..., páxs. 159-169. Amplío esta hipótese en M. Fernández CAlo, "Plinio, o Parroquial Suevo, e a evolución estrutural do poder local galaico na Antigüidade", [en prensa].
} 
no que verdadeiramente subxace neles: a súa condición de provincias eclesiásticas, e xa que logo de xurisdicións territoriais cunha presumíbel correspondencia civil. Propónse, con todo, antes de afondarmos neste factor, valorarmos a potencialidade da súa influencia no contexto histórico no que os synodi foron creados. En efecto, as modificacións da territorialidade metropolitana de certas igrexas provinciais, e nomeadamente a súa bipartición, conforman un paradigma con certa incidencia na Tardoantigüidade, do que os synodi suevo-católicos constitúen unha manifestación concreta. Por esta razón, a análise illada dos synodi devén insuficiente, e cobra sentido a súa incardinación no paradigma tardo-antigo a través dos seus exemplos análogos: os antecedentes baixo-romanos, a provincia Carthaginensis visigoda, e a Gran Bretaña anglo-saxona. Como se amosará, teimudamente aparece en todos eles a influencia do factor político. Por iso, esta contextualización histórica non só servirá para afondarmos na comprensión dos synodi, senón para amosarmos a conveniencia de incluír, e mesmo privilexiarmos, a análise das súas implicacións políticas.

\section{ANTECEDENTES DE BIPARTICIÓNS METROPOLITANAS}

A creación dos synodi e a consecuente bipartición da provincia eclesiástica da Gallaecia conforman unha innovación anómala no seu contexto histórico. Xa dous séculos antes do período suevo-católico da Gallaecia, os concilios ecuménicos e orientais baixo-romanos, preocupados por arrombaren a xerarquía eclesiástica supra-local, definiran con grande exactitude a dignidade metropolitana como a potestas que o bispo da capital administrativa de cada provincia tería sobre os demais bispos co-provinciais, ao que se engadirían logo múltiples competencias e prerrogativas derivadas ${ }^{48}$. Este ordenamento canónico sancionou a correspondencia entre as circunscricións locais e provinciais da Igrexa verbo ás da administración civil baixo-romana pre-existente ${ }^{49}$. Con todo, tan perfecta equiparación lexislativa tivo unha plasmación moi diversa no funcionamento real da Igrexa tardo-antiga.

\footnotetext{
48 Cómpre citarmos, pola súa significancia, Conc. Nicenum, canons 4 e 6; Conc. Sardicensis, c. 9; Conc. Antiochenum, cc. 9, 13, 16 e 19; Conc. Laodicenum, c. 12.

49 Cfr. Pierre David, La métropole ecclésiastique de Galice du VIII e au XIe siècle, Coimbra, Universidade de Coimbra-Instituto de Estudos Históricos Doutor António de Vasconcelos, 1947, páx. 5; Bryan Ward-Perkins, "The Cities", en Averil Cameron e Peter Garnsey, P. (eds), The Cambridge Ancient History, t. XIII, Cambridge, Cambridge University Press, 1998, páx. 400; Meritxell Pérez MARTínez, "La burocracia episcopal en la Hispania Tardorromana y visigótica (siglos IV y VII)", Studia Historica, 18-19 (2000-2001), páxs. 18-19; J. C. Rivas Fernández, Antigüedad..., páx. 130; J. Escalona Monge, "Patrones de fragmentación...", páx. 190; O. NúÑez García, Un novo deus..., páx. 35; M. Fernández Calo, A organización..., páx. 91.
} 
Neste senso, é moi reveladora a querela eclesiástica que se desenvolveu entre os séculos IV e V no sur das Galias. A comezos do V, o traslado a Arles do prefecto do pretorio das Galias dende Tréveris e a do vicario das Septem Prouinciae dende Bordeos, amais do posterior goberno na antedita cidade do usurpador Constantino III e de seguido o do seu vencedor o xeneral honoriano Constancio, estiveron detrás da senlla promoción metropolitana da igrexa arelatense. Nestas circunstancias, o papa Zósimo (417-418) tentaría incrementar a influencia da súa sé apostólica no sur das Galias recoñecendo ao bispo Patroclo de Arles como metropolitano das provincias Viennensis e Narbonensis prima e secunda; pero a resistencia dos metropolitanos afectados -Simplicio de Vienne, Hilario de Narbona e o anti-canónico Próculo de Marsella, metropolitano dunha provincia allea-, levaría ao recoñecemento no concilio -ou concilios-de Turín da potestas metropolitana do prelado da capital de cada provincia. Pero a igrexa de Arles mantería a súa pretensión metropolitana, o que finalmente, no 450, resolvería salomonicamente o papa León I (440-461) coa división latitudinal da provincia eclesiástica da Viennensis entre Arles e Vienne ${ }^{50}$, bipartición que grosso modo ficaría ata o réxime concordatario napoleónico e a adaptación da Igrexa francesa ao ordenamento civil departamental, no século $\mathrm{XIX}^{51}$.

Alén disto, existe unha controversia historiográfica arredor da data de celebración do(s) concilio(s) de Turín, que se fixera coincidir con esta conxuntura político-administrativa e eclesiástica. Semella que puido ser un só e reunirse xa no 398/399: antes, xa que logo, das transcendentais mudanzas no ordenamento político-administrativo das Galias. Con todo, as achegas historiográficas que parten desta idea seguen a atoparen detrás das deliberacións turinenses a influencia indirecta do poder temporal. Concretamente, o asentamento da corte de Honorio (395-423) na cidade de Milán, antes do seu traslado a Rávena no 402, motivaría ao metropolitano milanés Simplicano a incrementar a influencia da súa igrexa, sé imperial, a través da convocatoria do concilio de Turín, no que se resolverían, conforme ás normas canónicas e os seus intereses, as controversias eclesiásticas do sur das Galias ${ }^{52}$.

A influencia do poder temporal nas modificacións do artellamento eclesiástico, que no exemplo anterior só albiscamos indirectamente, foi tamén directa noutras ocasións. Sabido é que a "paz da Igrexa" do século IV impulsara amplamente o solapamento competencial entre as autoridades civís e as relixiosas, sobre todo a

\footnotetext{
50 André Chastagnol, La fin du monde antique: de Stilicon à Justinien (Vé siècle et début VIe), Paris, Nouvelles Editions Latines, 1976, páxs. 29-30.

51 Véxase Jean-Baptiste Jeangène Vilmer, "Commentaire du Concordat de 1801 entre la France et le Saint-Siège”, Revue d'Histoire Ecclésiastique, 102, 1 (2007), páxs. 139-140.

52 Ralph W. MathisEn, "The Council of Turin (398/399) and the Reorganization of Gaul ca. 395/406", Journal of Late Antiquity, 6, nº. 2 (2014), páxs. 302-304.
} 
nivel local ${ }^{53}$. Pero no poleiro do poder, os emperadores disfrutaran dunha posición privilexiada para interferiren nos asuntos eclesiásticos. O cesaropapismo, como práctica política, non é unha innovación medieval. O emperador romano-cristián, dominus, amais de convocar os concilios ecuménicos e favorecer determinadas posturas teolóxicas, implicaríase tamén no goberno da Igrexa. Á altura do século $\mathrm{V}$, o poder temporal impulsara directamente, por medio da lexislación, a determinados prelados afectos coa dignidade metropolitana, provocando desordes e controversias. Os padres reunidos no concilio ecuménico de Calcedonia do 451 lexislaron contra esta práctica, estipulando que non se enaxenasen as provincias eclesiásticas e que os bispos gratificados coa dignidade metropolitana polo Emperador a disfrutasen só de nome (nomine solum fruantur), recoñecendo así, coma sempre, que a potestas metropolitana unicamente correspondería ao bispo da capital provincial ${ }^{54}$.

É improbábel que a Igrexa galaico-sueva non tivese constancia desta norma, e máis tendo presente que Martiño Dumiense procedía do Oriente e se encargara de compilar unha escolma canonolóxica baseada nos concilios ecuménicos e orientais, os capitula Martini lidos no segundo concilio de Braga. O referido canon calcedonense, certamente, non aparece; mais si varios referidos á potestas e ás competencias metropolitanas ${ }^{55}$ : as mesmas que, para o bispo de Braga, se terían visto enaxenadas antes deste concilio coa bipartición metropolitana.

Importa, de calquera xeito, constatarmos que a evidencia positiva identifica insistentemente un nidio factor político, o rol do poder temporal, detrás das modificacións e anomalías que, verbo á lexislación canónica, se subscitaron ao longo da Tardoantigüidade na xeografía eclesiástica. Así como asumimos a influencia do poder temporal no propio artellamento provincial previo no que se basearan as xurisdicións metropolitanas da Igrexa, tamén cómpre identificala, directa ou indirectamente, detrás da reformulación das mesmas.

\section{A BIPARTICIÓN DA CARTHAGINENSIS HISPANO-VISIGODA}

O único caso análogo de bipartición dunha provincia eclesiástica no marco histórico inmediato da Gallaecia suevo-católica atópase na Carthaginensis coetánea,

\footnotetext{
53 José Ramón AJA SÁncheZ, "Innovaciones bajo-imperiales en el modelo de urbs: el obispo cristiano y su influjo en la organización urbana", en Antonio Rodríguez Colmenero, Los orígenes de la ciudad en el noroeste hispánico, t. II, Lugo, Deputación Provincial de Lugo, 1998; M. Pérez Martínez, "La burocracia...", páx. 23; Michael GADDIs, "The Political Church: Religion and the State", en Philip Rousseau, A Companion to Late Antiquity, Chichester, Blackwell, 2014, páx. 524; M. FernÁNDEZ CaLo, A organización..., páxs. 90-92.

${ }^{54}$ Conc. Chalcedonensis, canon 10.

55 Conc. Brac. II, capitula Martini, canons 2-4, 7 e 18.
} 
dividida entre as sés metropolitanas de Cartaxena e Toledo. Este conforma, sen dúbida, un exemplo paradigmático da determinante influencia do poder temporal sobre a definición do ordenamento eclesiástico tardo-antigo.

A implantación bárbara na Península Ibérica a comezos do século $\mathrm{V}$ alterara significativamente o artellamento administrativo baixo-romano pre-existente, ao responder de feito a eventualidades político-militares, máis do que a unha suplantación ordenada da auctoritas imperial previa ou a unha planificación a longo prazo. Os visigodos obtiveran o gálico val do Garona e a súa sedes regia de Toulouse en virtude do foedus do 418. Este fulcro territorial fora constantemente ampliado, tanto nas Galias coma na Península Ibérica, nas seguintes décadas. A comezos do século VI, pola contra, serían expulsados das Galias debido á súa derrota fronte aos francos en Vouillé (507). Daquela, o dominio político visigodo viraría no eixo Mérida-Toledo-Zaragoza, a vella provincia baixo-romana Tarraconensis, e a Septimania, a porción da Narbonensis que deran retido nas Galias. A Gallaecia e Lusitania noroccidental suevas, o norte cántabro e vascón, amplas porcións do sur hispánico, cuxos poderosos possessores e bispos mantiveran a autonomía das súas cidades durante todo o século anterior fronte as apetencias bárbaras $^{56}$, ficaran en meirande ou menor medida alleos a este dominio político, independentemente das relacións de co-provincialidade que compartiran no período baixo-romano previo.

A documentación histórica dispoñíbel amósanos que a adaptación da Igrexa ao novo ordenamento político non foi inmediata nin doada, mais si efectiva a mediados do século VI. No 516, por exemplo, aínda temos constancia de que o bispo Héctor de Cartaxena, sé metropolitana daquela non dominada polos visigodos, acodía ao concilio hispano-visigodo de Tarragona ${ }^{57}$. Se cadra Héctor de Cartaxena buscase apoio nos seus colegas extra-provinciais -e a esas alturas, de feito, estranxeiros- contra a desautorización á que estaba a ser sometido na porción da súa provincia dominada polos visigodos ${ }^{58}$. En efecto, durante boa parte do século VI, a igrexa de Toledo asistiría a un proceso de progresiva afirmación eclesiástica, paralela, mais non exactamente coincidente, á súa senlla consolidación política como sedes regia, por ser esta, de feito, posterior: en ningún caso anterior ao

\footnotetext{
56 P. Ubric Rabaneda, La Iglesia..., passim; John Hugo Wolfgang Gideon Liebeschuetz, "Administration and Politics in the Cities of the Fifth to the mid Seventh Century", en Averil Cameron, Bryan Ward-Perkins e Michel Whitby, The Cambridge Ancient History, t. XIV, Cambridge, Cambridge University Press, 2007, páx. 207, nota 10; Peter Heather, "State, Lordship and Community in the West (c. A.D. 400-600)", en Averil Cameron, Bryan Ward-Perkins e Michel Whitby, The Cambridge Ancient History, t. XIV, Cambridge, Cambridge University Press, 2007, páx. 455.

${ }^{57}$ Conc. Tarraconensis, subs.

58 Josep Vilella Masana: "Los concilios eclesiásticos hispanos del período visigodo-arriano: análisis histórico-prosopográfico", Medieval Prosopography, 25 (2008), páxs. 5 e 12.
} 
reinado de Teudis (531-548) $)^{59}$. Toledo situárase na Carthaginensis baixo-romana, polo que canonicamente sería sufragánea da sé metropolitana de Cartaxena. Esta cidade, en troques, mantivera, canda todo o ámbito sudoriental marítimo da súa vella provincia, a independencia fronte os visigodos ata o reinado do xa mencionado Teudis ${ }^{60}$. Arredada politicamente, pois, da súa metrópole eclesiástica, e presumibelmente amparada polo poder temporal visigodo-ariano, canda menos dende a década do 530 a igrexa toledana afirmaría a súa potestas metropolitana na súa contorna xeográfica, as Carpetania e Celtiberia hispano-visigodas. Descontando o ámbito tarraconense, tamén afectado, este proceso tivo principalmente dous ámbitos de acción: a exclusión da independente sé metropolitana de Cartaxena; e a inclusión do territorium Palentini, galaico na Baixa Romanidade, o cal, malia se inserir no dominio visigodo posibelmente xa dende o $457^{61}$, semella ter mantido durante todo o primeiro terzo do século VI a súa relación tradicional coa Igrexa galaica, que só resultou abolida neste tempo ${ }^{62}$.

A afirmación metropolitana da igrexa de Toledo ocorre probabelmente durante a prelatura de Montano ( $c$ a. 531), o primeiro que as fontes históricas definen implicitamente como metropolitano provincial: "qui in metropoli est"63. Se cadra o contrapunto da división metropolitana da Carthaginensis se atope no concilio de Valencia do 546, que reuniría aos bispos da metade sudoriental e marítima da provincia, e entre eles ao presumibelmente cartaxinense Celsino; do mesmo xeito que, dúas décadas antes, o antedito concilio de Toledo reunira os da metade noroccidental e interior ${ }^{64}$. Isto significa que o presumíbel dominio visigodo de todo este ámbito xeográfico na década do 540 non chegou a unificar a nivel eclesiástico a provincia; embora cumpriría matizarmos que Celsino, se realmente era o prelado cartaxinense, non asinou as actas conciliares de Valencia, como correspondería, en calidade de metropolitano ${ }^{65}$.

A presumíbel tendencia deica a reunificación eclesiástica da Carthaginensis sería axiña esgazada pola intervención bizantina do 552, plasmación hispana do programa xeo-político xustinianeo da recuperatio Imperii. No medio da guerra civil entre Axila e Atanaxildo, os bizantinos, inicialmente intervindo a prol do segundo, faríanse con todo o ámbito hispano-meridional, incluída Cartaxena,

${ }_{59}$ Cfr. P. C. Díaz Martínez, "La Hispania visigoda...”, páx. 361.

${ }^{60}$ Cfr. ibíd., páxs. 395-396; J. Vilella Masana, "Los concilios...”, páx. 5.

${ }^{61}$ Hyd., Chron., [179] 186.

${ }^{62}$ Conc. Toletanum II, Epistola ad Palentinos e Epistola ad Thuribium; cfr. José Orlandis Rovira, "Las relaciones intereclesiales de la Hispania visigótica", Communio, 12 (1972), páx. 413. Luis

A. García Moreno, "La Iglesia y el cristianismo en la Galecia de época sueva", Antigüedad y cristianismo, 23 (2006), páx. 40; M. Fernández Calo, A organización..., páxs. 108-109.

${ }^{63}$ Conc. Tol. II, sane iuxta...; cfr. J. Vilella Masana, "Los concilios...”, páx. 29.

${ }^{64}$ J. Vilella Masana, "Los concilios...", páxs. 5 e 10

${ }_{65}$ Conc. Valentinum, subs. 
sobre o que se instauraría a provincia Spania ${ }^{66}$. Isto sancionaría, outra volta, a bipartición metropolitana da Carthaginensis ata o século seguinte, por mor da dicotomía política visigodo-bizantina ${ }^{67}$.

En suma, a bipartición metropolitana da Carthaginensis tardo-antiga insiste na influencia do poder temporal na definición do ordenamento metropolitano da Igrexa. Esta simplemente adaptou, co seu propio ritmo, as innovacións xurisdicionais dos estados. Pero foron, de calquera xeito, as dinámicas xeo-políticas as que condicionaron neste caso a dicotomía eclesiástica.

\section{A BIPARTICIÓN DA IGREXA ANGLO-SAXONA}

Os synodi suevo-católicos teñen aínda outra lectura histórica: a bipartición eclesiástica dun dominio político recén integrado na Igrexa católica. Contamos tamén para isto cunha analoxía vindeira, embora agora diacrónica: a conformación na Gran Bretaña anglo-saxona de dúas provincias eclesiásticas canda a conversión dos seus reinos ao cristianismo católico-romano ${ }^{68}$.

A significativa implantación eclesiástica que presumibelmente tería acadado a Britannia baixo-romana no século IV trocaríase no V pola retracción do cristianismo e a emerxencia das relixións tradicionais. Isto vencéllase ao(s) abandono(s) militar(es) da illa, ao revival da súa cultura tradicional e, por suposto, á implantación de poboacións pagás, xermano-occidentais -fundamentalmente anglos e saxóns, e en menor medida xutos-e gaélicas, en detrimento dos britano-romanos, autóctonos e amplamente cristiáns.

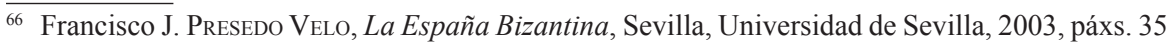
e seguintes; P. C. DíAz MarTíneZ, "La Hispania visigoda...”, páxs. 351-353.

67 Zacarías García Villada, Historia Eclesiástica de España II: La Iglesia desde la invasión de los pueblos germánicos en 409 hasta la caída de la monarquía visigoda en $711,1^{\mathrm{a}}$ parte, Madrid, Razón y Fe, 1932, páx. 204; P. David, La métropole..., páx. 6; Antonino GonzÁlez Blanco, "El decreto de Gundemaro y la historia del siglo VII", Antigüedad y cristianismo, 3 (1986), páx. 162; Federico Mario Beltrán ToRreira, "El conflicto por la primacía eclesiástica de la Cartaginense y el III Concilio de Toledo", en Concilio III de Toledo: XIV centenario: 589-1989, Toledo, Arzobispado de Toledo, 1991; J. Vilella Masana, “Los concilios...”, páx. 5; M. Fernández Calo, A organización..., páxs. $117-118$.

${ }^{68}$ Certamente, incrementarmos o horizonte comparativo multiplicaría o número destas analoxías. Coido que o exemplo máis obxectivamente achegado ao caso suevo é a bipartición do Reino de Hungría en dúas sés metropolitanas: Esztergom, a máis antiga e primada, e Kalocsa. Aquí, o factor político fica desdebuxado, canda menos segundo as tradicións eclesiásticas vencelladas: cfr. Nora Berend, Przemysław Urbańczyo e Przemysław Wiszewski, Central Europe in the High Middle Ages: Bohemia, Hungary and Poland, c. 900-c. 1300, Cambridge, Cambridge University Press, 2013, páxs. 333-334. Con todo, este caso, malia a súa evidente afinidade, correspóndese a un contexto cronolóxico moi diferente, o século XI, o que invita a centrarmos o exame histórico arriba desenvolvido no devandito caso anglo-saxón.
} 
A remates do século VI, o cristianismo, difundido dende o seu novo fulcro irlandés, xeneralizárase a todas as poboacións célticas - britónicas e gaélicas-, mais non ás xermánicas "anglo-saxonas", que ocupaban toda a metade sudoriental da illa. Neste contexto, a tradición reporta que o papa Gregorio I Magno (590-604) patrocinaría a que se veu en denominar a "misión gregoriana" do monxe bieito Agostiño de Canterbury. Tal intervención papal atópase motivada pola evanxelización dos anglo-saxóns pagáns e a conformación dunha Igrexa xerárquica e territorial homologada á católica, fronte ás igrexas célticas das Illas Británicas, de dependencia persoal ou xentilicia, moi diversas e decote sen xerarquías supra-locais ${ }^{69}$. Tamén se especula un factor galo-franco, se é que Childeberto II de Austrasia (570-595) presionou ao papado para contrarrestar a influencia dinástica do seu rival Clotario II (584-629), daquela rei de Neustria, no reino anglo-saxón -en realidade de orixe xuta- de $\mathrm{Kent}^{70}$.

Logo da súa primeira estancia en Kent, Agostiño voltaría ao continente, sendo ordeado archiepiscopus genti Anglorum en Arles ${ }^{71}$. Cumprido este requisito sacramental, de volta á illa, Gregorio cominaríao a designar dous bispos metropolitanos en Londres e York, e a nomear canda eles a outros doce bispos per loca singula para cadansúa circunscrición metropolitana ${ }^{72}$. Asúmese xeralmente que tal programa gregoriano inicial procuraría artellar a nova Igrexa anglo-saxona sobre a vella territorialidade provincial romana ${ }^{73}$, embora fique incerta a correspondencia de tal bipartición metropolitana coas catro provincias civís - Britannia Prima, Secunda, Flauia e Maxima; ou ata cinco, coa adición de Ualentia- ${ }^{74}$, que dividiran o espazo britano-romano terminal ocupado a posteriori polos reinos anglo-saxóns.

Xa nesta circunstancia se atopa unha analoxía coa bipartición suevo-católica: un espazo político - no caso británico composto por múltiples reinos; no galaico por un só- convertido ao catolicismo por influencia dun misioneiro -Agostiño de Canterbury e Martiño de Dume, respectivamente-, que se organiza en dúas provincias eclesiásticas. Cómpre engadirmos aínda que, nunha carta gregoriana reproducida por Beda o Venerábel, tamén se empregaría a denominación "synodus" como referencia ao conxunto dos bispos da provincia eclesiástica londinense ${ }^{75}$ :

\footnotetext{
69 Arredor da diversidade de réximes eclesiásticos "célticos", véxase Simon Young, Bretoña: camiños novos, Noia, Toxosoutos, 2002, páxs. 36-40.

70 Marilyn Dunn, The Christianization of the Anglo-Saxons, c.597-c.700: Discourses of Life, Death and Afterlife, London-New York, Continuum, 2010, páx. 49.

71 Beda o Venerábel, Historia Ecclesiastica gentis Anglorum, I, 27.

72 Ibíd., I, 29.

73 M. Dunn, The Christianization..., páx. 56; Barbara Yorke, The Conversion of Britain: Religion, Politics and Society in Britain, c.600-800, London-New York, Routledge, 2014, páx. 151.

74 Cfr. Anthony R. Birley, The Roman Government of Britain, Oxford, Oxford University Press, 2005, páxs. 397-400.

75 Beda, Hist. Eccl., I, 29.
} 
Quatinus Lundoniensis ciuitatis episcopus semper in posterum a synodo propria debeat consecrari.

Esta mención, con todo, non semella adscribíbel aos synodi da Gallaecia suevo-católica, ao referirse, a priori, á reunión física, conciliar, dos bispos da provincia; e non ao distrito eclesiástico composto polas súas sés, coma no caso galaico.

O programa gregoriano inicial nunca foi cumprido. A misión de Agostiño viuse truncada polas circunstancias políticas dos reinos anglo-saxóns: concretamente, o acceso de novos monarcas contrarios á implantación eclesiástica derrogou durante un tempo os bispados de Londres e York, e obrigou a establecer eventualmente a única sé metropolitana da illa en Canterbury, no reino de Kent ${ }^{76}$.

As fluctuacións, tanto do poder político-militar dos reinos anglo-saxóns coma da actitude dos seus monarcas verbo ao cristianismo, condicionaron a implantación eclesiástica nos dous séculos seguintes, ata a bipartición metropolitana definitiva da Igrexa anglo-saxona entre Canterbury e York. En efecto, a evolución do ordenamento da Igrexa anglo-saxona was not controlled from Canterbury, but relied on decisions made by individual kings ${ }^{77}$. Neste senso, foi a retracción do reino de Nortumbria no século VIII, que o arredou dos asuntos do sur da illa, o que conduciría á restauración da dignidade metropolitana do seu bispado de York no 735. Do mesmo xeito, no 787, as discrepancias do rei Offa de Mercia e o bispo Jaenbert de Canterbury conduciron ao primeiro a establecer, coa aquiescencia papal, unha nova sé metropolitana en Lichfield, que só perduraría ata o deceso do monarca no $803^{78}$.

$\mathrm{O}$ caso da Igrexa anglo-saxona redunda na determinante influencia do poder temporal na ordenación eclesiástica, que xa se indicou en todos os exemplos antecedentes; pero apórtanos ademais a noción da fluctuación desta influencia canda as circunstancias conxunturais do poder político.

AFONDANDO NA INFLUENCIA DO PODER TEMPORAL SOBRE A DEFINICIÓN DOS SYNODI

Ata aquí presentáronse varios exemplos significativos de procesos de reformulación eclesiástica análogos á bipartición metropolitana da Gallaecia suevo-católica: en todos eles é indisociábel a influencia do poder temporal. Con todo, este "factor temporal" fica amplamente eludido na historiografía arredor da

\footnotetext{
${ }_{76}$ B. Yorke, The Conversion..., páx. 151.

77 Ibíd.

78 Ibíd., páxs. 150-155.
} 
bipartición galaica. Cómpre, pois, en consonancia co seu contexto eclesiástico coetáneo, afondarmos neste vieiro, identificarmos as súas implicacións, e comprendermos a realidade estrutural que se atopa detrás da bipartición metropolitana da Gallaecia suevo-católica.

Fronte á xeneralizada elusión do devandito factor na historiografía moderna, Demetrio Mansilla Reoyo constitúe unha notábel excepción, ao ter aludido, dun xeito superficial pero efectivo, a dúas hipotéticas asociacións entre os synodi e o poder temporal: unha intervención rexia en tempo de Teodomiro (ante quem $570)$, ou un efecto da confrontación sueva no "período de faccións" (456-470) 79 . Con todo, non afondou nestas consideracións, nin se decidiu por unha das dúas hipóteses enunciadas. A segunda é sen dúbida a máis significativa para o presente estudo, e axiña se valorará en fondura.

Atendendo aos antecedentes e aos casos análogos de modificación de xurisdicións metropolitanas, a influencia do poder temporal na creación dos synodi puido ser tanto directa coma indirecta. Como se amosará de seguido, tales posibilidades non son necesariamente excluíntes, senón complementarias.

A influencia directa do poder temporal é dende logo explícita no controvertido discurso de Teodomiro, onde se asocia a convocatoria do suposto concilio de Lugo do 569 e a senlla iniciativa da reformulación da Igrexa galaica á propia monarquía, e concretamente ao devandito Teodomiro ${ }^{80}$ :

Tempore Sueuorum, sub era DCVII die kalendarum Ianuarii, Theodemirus princeps idem Sueuorum concilium in ciuitate Luco fieri praecepit.

Deste xeito, a creación dos synodi podería terse por unha actuación "cesaropapista" $"$, decretada ou cominada polo príncipe e cumprida pola Igrexa. Cumpriría aínda, con todo, atoparmos unha motivación para tan directa implicación monárquica, que complementase as razóns extra-políticas, parciais cando non inverosímiles, xa sintetizadas noutra sección deste estudo. A analoxía do Imperio Romano-Cristián reporta unha razón evidente na súa simplicidade: coa súa actuación cesaropapista, o monarca promovería a igrexa lucense para favorecer arbitrariamente ao seu prelado. Neste caso, a razón primeira da bipartición metropolitana atoparíase na afeizón do bispo lucense, se cadra xa Nitixio -bispo no

79 D. Mansilla Reoyo, “Orígenes...”, páx. 278.

80 Par. Suev., praef.

81 Emprega expresamente tal denominación, verbo á política eclesiástica da monarquía sueva, A. López CARreira, O reino..., páx. 74. 
$572^{82}$, ao monarca suevo, sobre cuxa identidade voltaremos de contado. Tal solución atoparía o atranco da prohibición canónica vixente dende o século anterior, e xa tratada no presente estudo, da enaxenación das provincias eclesiásticas. Isto, con todo, non supón unha refutación absoluta de tal posibilidade, pois obviamente a realidade histórica da Gallaecia diferiu da ideal canonoloxía ecuménica. É moi significativo, neste senso, o amplo testemuño da -anti-canónica- interferencia do poder temporal franco-merovinxio na Igrexa gala coetánea, incluídas as promocións episcopais ${ }^{83}$.

Como xa se amosou ${ }^{84}$, os synodi foron creados entre os anos 561 e 572, de xeito que os reis implicados na súa creación puideron ser Ariamiro (ca. 561), Teodomiro (ante quem 570), e Miro (post quem 570). Elúdese nesta relación a información que reporta o controvertido discurso de Teodomiro ${ }^{85}$, que como xa se mencionou vencella univocamente este monarca coa reformulación eclesiástica do Reino. Acredítese ou óbstese a fiabilidade deste documento, a opción de Teodomiro é dende logo plausíbel, pois a acotación máxima do seu reinado, 561/570, incerta e solapada á de Ariamiro ${ }^{86}$, ocupa a práctica totalidade do intervalo de creación dos synodi (561/572).

A influencia indirecta do poder temporal, pola súa banda, estaría determinada non pola implicación deste na creación dos synodi, senón por seren estes unha consecuencia colateral da situación político-administrativa vixente. Outra volta, o controvertido discurso de Teodomiro aporta unha razón explícita pola que Lugo sería escolleita segunda metrópole da Gallaecia ${ }^{87}$ :

Quia ibi erat terminus de confinitimis Episcopis, et ad ipsum locum Lucensem grandis semper erat coniunctio [concilio] Sueuorum.

Ou sexa, a súa localización excéntrica e -entra a razón política-a antiga celebración nela das asembleas suevas. Xeralmente, embora non exista unha evidencia positiva concluínte ${ }^{88}$, asúmese que a sedes regia da Gallaecia suevo-católica foi Braga. Isto, con todo, non se corresponde en absoluto coa situación previa. Lugo fora, abofé, sé monárquica sueva ${ }^{89}$, e escenario do intercambio de varias

${ }_{82}$ Conc. Brac. II, praef; subs.

83 Cfr. Ian Wood, The Merovingian Kingdoms, 450-751, London-New York, Routledge, 2014, páxs. 77-80.

${ }^{84}$ Véxase arriba $\S 1$.

${ }^{85}$ Par. Suev., praef.

${ }^{86}$ Cfr. Conc. Brac. I, praef; Ioh. Bicl., Chron., Iustinus, IV, 4.

${ }^{87}$ Par. Suev., praef.

88 M. Fernández Calo, A organización..., páxs. 114-115.

${ }^{89}$ Ibíd. páx. 96; cfr. P. C. Díaz Martínez, El reino..., páxs. 129-132. 
embaixadas suevo-visigodas ${ }^{90}$, antes e despois de que o caudillo Remismundo reunificase aos suevos da Gallaecia (ca. 464). Ignórase a significancia política desta cidade dentro do Reino no século seguinte; pero se cadra a igrexa de Lugo tería adquirido por esta primitiva capitalidade un certo prestixio eclesiástico no ámbito setentrional da Gallaecia que lle permitise rivalizar coa sé de Braga; culminando isto na bipartición dos synodi no século seguinte. A casuística sería certamente análoga ao Milán de Simpliciano, corte imperial do Occidente, ou ao Toledo de Montano, principal centro político visigodo-ariano da súa contorna: igrexas emerxentes pola contigüidade do poder temporal ${ }^{91}$.

Pero aínda resta por explorarmos un segundo vieiro da influencia indirecta do poder temporal, imposto tamén polos exemplos análogos e antecedentes contemplados $^{92}$. En efecto, as modificacións da territorialidade metropolitana estiveron decote motivadas por outras análogas na civil. Neste senso, cómpre formularmos unha hipótese relativa á correspondencia dos synodi verbo a unhas circunscricións civís previas, que a posteriori tivese reproducido a Igrexa galaica no seu artellamento territorial ${ }^{93}$. A adaptación da Igrexa a tales hipotéticas circunscricións puido estar ou non directamente mediatizada polo poder temporal. Por esta razón, as posibilidades dunha influencia directa e indirecta do poder temporal son potencialmente complementarias.

Se cadra xa Pierre David valorase esta mesma influencia indirecta cando, obstando a natureza metropolitana dos synodi, intuía detrás dos mesmos une mesure d'organization administrative, de décentralisation ${ }^{94}$. Con todo, embora non afondase nesta idea nin o concretase dun xeito explícito, semella referirse especificamente á administración da Igrexa, non á do Estado.

Emporiso, a correspondencia dos synodi eclesiásticos con senllas circunscricións civís devén inverosímil en termos de simultaneidade. A bipartición administrativa dun Estado en dúas metades é como mínimo unha innovación tan anómala coma a senlla bipartición da súa Igrexa. $\mathrm{O}$ antecedente que constitúe a coñecida e definitiva partición teodosiana do Imperio Romano entre Oriente e Occidente no 395 responde de feito a unha longa tradición imperial iniciada polos tetrarcas Diocleciano e Maximiano, destinada á división das funcións administrativas e militares ${ }^{95}$. Neste senso, un antecedente para a hipotética bipartición administrativa

\footnotetext{
90 Hyd., Chron., 215 [219]; cfr. Pseudo-Fredegario, Chronica, II, 55.

91 Cfr., respectivamente, $\S \S 3-4$.

92 Véxase arriba $\S \S 3-5$.

93 M. Fernández Calo, A organización..., páxs. 117-118.

94 P. David, Études..., páxs. 65-66.

95 Gonzalo Bravo Castañeda, Diocleciano y las reformas administrativas del Imperio, Madrid, Akal, 1991, páx. 10; David S. PotTer, "The Transformation of the Empire: 253-337 CE”, en D. S. Potter, The Blackwell Companion to the Roman Empire, Malden-Oxford-Carlton, Blackwell, 2006,
} 
galaico-sueva atoparíase na reformulación e duplicación da prefectura do pretorio polos tetrarcas e máis adiante por Constantino. A noción de terse dado na Gallaecia suevo-católica unha reforma administrativa análoga, logo calcada na bipartición eclesiástica, é certamente inverosímil. Embora o rexistro histórico non documente ningunha información explícita referente á burocracia suevo-católica, a priori non semella que unha reformulación deste calado responda nin á capacidade nin ás necesidades específicas deste Estado, canda menos atendendo ao contexto xeral dos reinos bárbaros do Occidente, pouco innovadores a nivel administrativo ${ }^{96}$.

A alternativa é, abofé, examinarmos se anteriormente á constancia histórica dos synodi existiu unha dicotomía política entre o norte o sur do espazo galaico-lusitano ocupado polos suevos. Identificada tal correspondencia, poderase valorar a súa influencia na definición dos synodi.

\section{O HIPOTÉTICO ANTECEDENTE POLÍTICO DOS SYNODI}

Como xa se amosou anteriormente, a dicotomía conventual da Gallaecia alto-romana, dividida precisamente entre os conuentus iuridici de Braga e Lugo, non se corresponde coa proxección territorial dos synodi, pois malia compartiren as súas cabeceiras administrativas, as áreas de Ourense e Tui, dependentes da metrópole lucense suevo-católica, se asignaran daquela á circunscrición bracarense ${ }^{97}$. Posteriormente, é posíbel que a instauración da provincia baixo-romana da Gallaecia derrogase os conuentus a nivel político-administrativo ${ }^{98}$, en cuxo caso ficarían, canda menos, como referencia coronímica oficiosa ${ }^{99}$.

Ficasen operativos ou non os conuentus iuridici na Gallaecia baixo-romana, o asentamento bárbaro ao remate deste período, no 409/411, reproduciría dende logo unha dicotomía territorial ${ }^{100}$ :

Subuersis memorata plagarum grassatione Hispaniae prouinciis, barbari, ad pacem ineundam, domino miserante conuersi sorte, ad inhabitandum sibi, prouinciarum diuidunt regiones. Gallaeciam

\footnotetext{
páx. 166; Francisco Javier Sanz Huesma, "Historia política”, en P. C. Díaz Martínez, C. Martínez Maza e F. J. Sanz Huesma, Hispania tardoantigua y visigoda, Madrid, Istmo, 2007, páx. 44; M. Fernández Calo, A organización..., páxs. 79-80.

96 Cfr. Chris Wickham, Framing the Early Middle Ages: Europe and the Mediterranean, 400-800, Oxford, Oxford University Press, 2005, páxs. 80 e seguintes; P. Heather, "State...".

97 Cfr. M. Fernández Calo, A organización..., páx. 223, mapa 4 e 227, mapa 8.

98 Pablo Ozcáriz Git, Los conventus de la Hispania Citerior, Madrid, Universidad Rey Juan Carlos, 2006, páx., 33; M. Fernández Calo, A organización..., páx. 83.

99 Cfr. Hyd., Chron., passim.

${ }^{100}$ Hyd., Chron., 41 [49].
} 
Uandali [Asdingi] occupant, et Sueui, sita in extremitate Oceani maris occidua.

Este episodio histórico ${ }^{101}$ refírese ao reparto da Península Ibérica polos bárbaros que irrumpiran nela no 409102; e concretamente á ocupación da Gallaecia polos vándalos asdingos e os suevos. Dado o reparto territorial previo ao asentamento, cómpre presumirmos que o espazo ocupado por cada pobo sería mutuamente excluínte. Con todo, non existe consenso historiográfico verbo á determinación destes dous espazos de asentamento. Os paradigmas manexados varían entre a lectura latitudinal e a lonxitudinal do reparto ${ }^{103}$. No primeiro caso, os vándalos terían ocupado o norte lucense da provincia e os suevos o sur bracarense ${ }^{104}$; no segundo, o ámbito mesetario da provincia correspondería aos vándalos, e o occidental atlántico -a Gallaecia stricto sensu-, aos suevos ${ }^{105}$. Obviamente, só no caso dunha lectura latitudinal se atoparía un antecedente dos synodi. Engádese a isto a saída dos vándalos á Baetica no $420^{106}$, que tería eliminado a dicotomía territorial e permitido a consolidación dos suevos na Gallaecia (420-429), amais da súa posterior auxe monárquica en todo o occidente da Península Ibérica $(429-456)^{107}$.

Con todo, o colapso do primeiro Reino Suevo no 456, concomitante á intervención do visigodo Teodorico II contra Requiario, reproduciría unha segunda dicotomía territorial na Gallaecia. Malia que os visigodos darían suplantado o poder suevo previo en Mérida e na meseta ${ }^{108}$, e expugnaran canda menos as cidades sitas na provincia baixo-romana da Gallaecia -e probabelmente dependencias suevas- de Porto, Braga, Astorga, Coianza e Palencia, amais de capturaren ao propio monarca suevo Requiario, retraeríanse nos anos seguintes dos asuntos deste espazo xeográfico. Tal proceso de inhibición política é incerto nos seus pormenores e motivacións, mais cómpre vencellalo á tentativa -finalmente infructuosa- do

\footnotetext{
${ }^{101}$ Cfr. Isid., Hist., 73; Fred., Chron., II, 50.

${ }^{102}$ Hyd., Chron., 34 [46].

${ }^{103}$ M. Fernández Calo, A organización..., páx. 99.

104 Jorge López Quiroga e Mónica Rodríguez Lovelle, “De los Vándalos a los Suevos en Galicia: una visión crítica sobre su instalación y organización territorial en el noroeste de la Península Ibérica en el siglo V”, Studia Historica, 13-14 (1994-1995), páxs. 422-423; F. N. SoAres, "Os concílios...”, páx. 63; J. López Quiroga, El final de la Antigüedad..., páx. 39.

${ }^{105}$ C. Torres Rodríguez, El reino..., páxs. 61-62; M. C. Díaz Martínez, "La Hispania visigoda...”, páxs. 256 e seguintes; íd., El reino..., passim.

${ }^{106}$ Hyd., Chron., 66 [74].

107 Véxase M. Fernández Calo, A organización..., páxs. 93-97 e 210, fig. 1.

108 Adolfo Jerónimo Domínguez Monedero, "La Chronica Caesaraugustana y la presunta penetración popular visigoda en Hispania”, Antigüedad y cristianismo, 3 (1986), páxs. 61-62; M. C. DíAz Martínez, "La Hispania visigoda...”, páx. 319.
} 
godo Aiulfo en se conformar o novo rei dos suevos ${ }^{109}$, e a atención visigoda doutros asuntos máis perentorios para a súa posición xeo-política: nomeadamente, as constantes intervencións militares na Baetica ${ }^{110}$. Isto condicionaría que o ámbito galaico ficase libre da influencia visigoda logo da campaña de Teodorico II, malia a súa virulencia neste mesmo espazo xeográfico. A conxuntura política subseguinte ficaría determinada por dous factores: o isolamento externo e a fragmentación interna. É nesta segunda variábel na que cómpre identificarmos o inmediato precedente político dos synodi ${ }^{111}$.

En efecto, logo do colapso da súa monarquía no 456, os suevos asentados na Gallaecia dividíronse en dúas faccións que disputarían a dignidade rexia para senllos caudillos, Frantán e Maldras ${ }^{112}$ :

Sueui in partes diuisi pacem ambiunt Gallaecorum; e quibus pars Framtano, pars Maldras regem appellant.

Se cadra a orixe destas faccións se atope na propia heteroxeneidade étnica, familiar e clientelar do pobo suevo dende o mesmo intre do seu asentamento ${ }^{113}$. Con todo, segundo xa expuxen noutra ocasión, a súa manifestación histórica logo do 456 permite diferenciar dous senllos ámbitos de actuación político-militar contrapostos para estes caudillos e as súas faccións no norte e no sur da Gallaecia ${ }^{114}$.

Tales ámbitos implicítanse en varias noticias hidacianas referentes aos episodios protagonizados polos caudillos suevos no "período de faccións" (456-464), case unha década de confrontación política interna entre as dúas faccións suevas, coa notábel implicación de múltiples poderes locais galaicos ${ }^{115}$. Estas noticias son as seguintes ${ }^{116}$ :

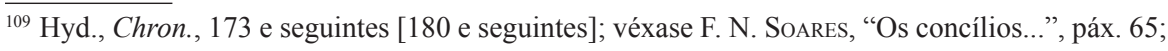
M. C. Díaz Martínez, El reino..., páx. 91; M. Fernández Calo, A organización..., páx. 95, nota 3. ${ }^{110}$ Hyd., Chron., 185 e seguintes [192 e seguintes]; véxase M. C. Díaz Martínez, El reino..., páx. 95; M. Fernández Calo, A organización..., páx. 95.

${ }^{111}$ D. Mansilla Reoyo, Orígenes..., páx. 278.

${ }^{112}$ Hyd., Chron., 181 [188].

113 P. C. Díaz Martínez, El reino..., páx. 112.

${ }^{114}$ M. Fernández Calo, A organización..., páx. 95; cfr. D. Mansilla Reoyo, "Orígenes...”, páx. 278; C. Torres Rodríguez, El reino...; Alain Tranoy, La Galice Romaine: recherches sur le nord-ouest de la péninsule ibérique dans l'Antiquité, Paris, Diffusion de Boccard, 1981, páx. 446; P. UBRIC Rabaneda, La Iglesia..., páx. 322; J. López Quiroga, El final de la Antigüedad..., páx. 42; M. C. Díaz Martínez, El reino..., páx. 95.

${ }^{115}$ Felipe ArIas VILAS, "A transición do mundo galaico-romano ó reino dos suevos", en José Manuel García Iglesias et al., Galicia Castrexa e Romana: Galicia Castreña y Romana, Lugo, Xunta de Galicia, 1997, páx. 292; M. C. Díaz Martínez, “Gallaecia: de Reino...”, páx. 256; César Candelas
} 
$1^{\mathrm{a}}$.- Maldras dirixe unha incursión na Lusitania ata Lisboa.

$2^{\mathrm{a}}$.- Frantán morre.

3 . - Maldras depreda na Gallaecia a carón do Douro.

$4^{\mathrm{a}}$.- Maldras depreda na Lusitania e Recimundo na Gallaecia.

$5^{\mathrm{a}}$.- Maldras mata ao seu irmán e toma Porto.

$6^{\mathrm{a}}$.- Intensifícase a hostilidade entre galaicos e suevos.

$7^{\mathrm{a}}$-- Maldras é asasinado.

$8^{\text {a }}$.- Os suevos de Lugo atacan aos Romani desta cidade.

9a . - Os visigodos atacan aos suevos de Lugo; o suevo Frumario ataca Chaves e apreixa ao seu bispo Hidacio.

$10^{\mathrm{a}}$.- Recimundo devasta aos Auregenses e o litoral do conuentus Lucensis.

$11^{\mathrm{a}}$.- Estoupa a confrontación entre Frumario e Recimundo.

$12^{\mathrm{a}}$.- Establécese a paz entre suevos e galaicos.

$13^{\text {a }}$.- Intercambio de embaixadas entre o suevo Remismundo e o visigodo Teodorico II en Lugo; os suevos rachan a paz cos galaicos.

$14^{\mathrm{a}}$.- Morto Frumario, Remismundo reclama a súa autoridade sobre todos os suevos.

Tales noticias determinan a influencia territorial de cada un dos caudillos do "período de faccións". Polos episodios que protagonizan, Maldras e Frumario sitúanse inequivocamente no ámbito meridional da Gallaecia; asemade Recimundo e Remismundo no setentrional. Presumibelmente, as mencións alternas destes dous últimos antropónimos, Recimundo e Remismundo, se deben a un erro de transmisión textual, referíndose de feito á mesma figura histórica ${ }^{117}$. Pola súa banda, ningún dato positivo permite ubicar do mesmo xeito a Frantán, mais si o feito de ser substituído nas mencións cronísticas por Recimundo, o que invita a considerarmos que o precedería á cabeza da facción setentrional. De acreditarmos nestas consideracións, determinaríase que, entre o 456 e o 464, se sucederon á fronte da facción meridional sueva Maldras e Frumario, mentres que na seten-

CoLODRÓN, "Plebs y aristocracia en el cronicón de Hidacio: la organización política hispanorromana en el siglo V", Polis, 13 (2001); M. C. Díaz Martínez, El reino..., páx. 166; M. Fernández Calo, A organización..., páxs. 103-108.

${ }^{116}$ Todas elas remitintes ao Chronicon de Hidacio de Chaves. Respectivamente, $\mathrm{n}^{\circ} .1: 181$ [188]; $\mathrm{n}^{\circ}$. 2: 182 [189]; $n^{\circ} .3: 183$ [190]; $n^{\circ} .4: 188$ [193]; $n^{\circ} .5: 190$ [195]; $n^{\circ} .6: 191$ [196]; $n^{\circ} .7: 193$ [198]; $n^{\circ} .8: 194$ [199]; $n^{\circ} .9: 196$ [201]; no. 10: 197 [202]; no. 11: 198 [203]; no. 12: 199 [204]; no. 13: 215 [219]; no. 14: 219 [223].

${ }^{117}$ M. C. Díaz Martínez, El reino..., páxs. 94 e 114; M. Fernández Calo, A organización..., páx. 95, nota 5 . 
trional, Frantán e Remismundo. Este último, finalmente, é o que se impón como único rei dos suevos ao remate do período.

Determínase, tamén, que o fulcro da facción setentrional fose Lugo, que se convertiría asemade no da Gallaecia sueva coa imposición de Remismundo como único rei no 464. O fulcro da facción meridional é incerto, mais se cadra se poida supoñer na contorna de Braga-Porto, polas accións específicas neste ámbito e a aparente importancia que tivera para a primeira dinastía sueva ${ }^{118}$ e para o godo Aiulfo $^{119}$.

A influencia territorial máxima de cada unha das faccións suevas, pola súa banda, fica determinada por cadansúa expedición máis extrema testemuñada: respectivamente, a máis setentrional da facción meridional, e a máis meridional da setentrional. Atopamos a primeira no ataque de Frumario contra Chaves; a segunda, aparentemente no ataque de Remismundo contra os Auregenses ${ }^{120}$.

A redución xeográfica concreta destes Auregenses non é completamente segura, embora semella poder aproximarse. Con excepcións ${ }^{121}$, xeralmente o devandito etnónimo se vén asociando aos montes Aregenses referidos por Xoán de Bíclaro o século seguinte; e aínda á Aregia de Isidoro de Sevilla ${ }^{122}$.

Canda menos no caso do etnónimo hidaciano que nos ocupa, a semellanza léxica co actual Ourense - Auriensis na súa forma latina, sen dúbida vencellada ao arcaico topónimo tardo-suevo Palla Aurea ${ }^{123}$ - ten motivado comunmente aos investigadores a se decidiren por unha redución xeográfica xenérica na contorna da devandita localidade; ou, pola mención "montes" coa que o testemuñaría o biclarense, ao vindeiro Macizo Galaico ${ }^{124}$. Se cadra se poida concretar, neste espazo,

$\overline{118}$ M. C. Díaz Martínez, El reino..., páxs. 129 e seguintes; M. Fernández Calo, A organización..., páxs. 107 e 114.

${ }^{119}$ Hyd., Chron., 180 [187].

${ }^{120}$ Véxase nota 116 , noticias $n^{\circ} .9$ e 10.

${ }^{121}$ Véxase Luis A. García Moreno, Leovigildo: unidad y diversidad de un reinado, Madrid, Real Academia de la Historia, 2008, páx. 73, para quen os Aregenses e a Aregia testemuñados no século VI estarían vencellados ao pobo ástur dos Luggones Arganticaeni; e non terían nada que ver, alén da semellanza fonética, cos Auregenses testemuñados por Hidacio o século anterior, pola presenza dun ditongo decrecente neste segundo etnónimo, inexistente no anterior. Deste xeito, os Auregenses do século V serían unha entidade socio-política distinta dos Aregenses do VI. Ségueno nesta postura disimilatoria R. BArroso et al., "Gallaecia Gothica...", páxs. 63-64. Óbstase analizarmos aquí as dispares reducións propostas por estes autores, por eludiren os Auregenses hidacianos que nos ocupan. ${ }^{122}$ Ioh. Bicl., Chron., Iustinus, IX, 2; Isid., Hist., 49.

${ }^{123}$ Par. Suev., IX, 2.

${ }^{124}$ Marcelo Macías, Cronicón de Idacio: versión castellana, con abundantes notas y aclaraciones, precedida de un estudio del insigne obispo y su obra, Ourense, 1906, páxs. 73-74, nota 40; Alain Tranoy, Hydace: Chronique, t. II, Paris, Éditions du Cerf, 1974, páx. 114; C. Torres Rodríguez, El reino..., páxs. 247-248; Edward Arthur Thompson, Romans and Barbarians: The Decline and 
o topónimo Oulego, parroquia do concello de Rubiás, na bisbarra de Valdeorras. Matizaríase a súa inexacta correspondencia léxica se o actual topónimo Oulego derivase dun étimo *Aureg(i)um análogo á forma isidoriana, en caso, factíbel mais certamente anómalo, dunha lateralización da vibrante simple intervocálica. Unha segunda concreción, que tampouco contradí a redución xenérica pero desta volta sen base positiva, é a de Fernández Guerra ${ }^{125}$, que asociaría o "señorío de Aspidio", senior loci dos montes Aregenses segundo Xoán de Bíclaro ${ }^{126}$, ás ecclesiae tardo-suevas aurienses de Cassauio, Pincia, Senabria, Calapa[cios] e Uerugio ${ }^{127}$.

Unha segunda redución dos Auregenses, proposta por Manuel Gomes de Lima Bezerra e afastada xa da contorna de Ourense, oporía a freguesía portuguesa, sita entre Tui e Ponte de Lima, de São Miguel de Aurega ${ }^{128}$. Neste caso, a localización variaría notabelmente en termos lonxitudinais, mais non latitudinais, polo que tamén a expedición contra os Auregenses sería a máis meridional das protagonizadas por Remismundo e a facción setentrional sueva.

Emporiso, unha terceira redución, "setentrional", que coido que aínda non ten sido observada, podería levar aos Auregenses ata o actual Valadouro, cuxa bisbarra conformou no Medievo a terra de Aurium ${ }^{129}$. O lacónico contexto que Hidacio proporciona para o episodio no que se nomean os Auregenses pode supór un argumento tanto en favor coma en contra desta redución ${ }^{130}$ :

\section{Rechimundus uicina sibi pariter Auregensium loca et Lucensis conuentus maritima populatur.}

\footnotetext{
Fall of the Western Empire, Madison, University of Wisconsin Press, 1982, páx. 294; Jorge LóPEZ Quiroga e Mónica Rodríguez Lovelle, "El problema del limes de época visigoda en Galicia: nuevas consideraciones a partir de una relectura de las fuentes escritas y arqueológicas", Guimarães, 104 (1994), páx. 84; J. López Quiroga, El final de la Antigüedad..., páx. 45; M. C. Díaz Martínez, El reino..., páxs. 125 e 147; M. Fernández CALo, A organización..., páxs. 124 e 227, mapa 8.

${ }^{125}$ Recollida en C. Torres Rodríguez, El reino..., páxs. 247-248

126 Véxase nota 122.

${ }^{127}$ Par. Suev., IX, 3; 7-8; 10-11.

${ }^{128}$ M. Macías, Cronicón de Idacio..., páxs. 73-74; José Antonio López SiLva, A Crónica de Idacio de Limia, bispo de Chaves, Ourense, Deputación Provincial, 2004, páx. 151, nota 189; A. LóPEZ Carreira, O reino..., páx. 56. Xa E. Flórez, España Sagrada, t. XXII, Madrid, 1798, páx. 259, editou unha doazón de dona Tareixa de Portugal á igrexa de Tui en 1125, na que se documenta esta freguesía: do etiam et concedo Ecclesiae S. Mariae Tudensis, et uobis Episcopo Domino Adefonso Ecclesiam $S$. Michaelis de Aurega in ripa Limiae.

${ }^{129}$ De feito, aparece sempre en ablativo: in Aurio. A primeira mención é o falso "testamento maior" de Odoario, supostamente datado no século VIII. De calquera xeito, abundan as referencias posteriores a este mesmo topónimo: véxase José Luis López SAngIL e Manuel Vidán Torreira, "El Tumbo Viejo de Lugo (Transcripción Completa)”, Estudios Mindonienses, 27 (2011), páxs. 29, 139 e 223.

${ }^{130}$ Hyd., Chron., 197 [202].
} 
Ambas as referencias coronímicas, Auregensium loca e Lucensis conuentus maritima $[$ loca], poderíanse referir así a un único episodio bélico: unha campaña do caudillo suevo Remismundo contra o norte marítimo da súa base territorial, Lugo. Se o contido do texto favorece efectivamente tal solución, a redación do mesmo, en troques, desbotaría a relación entrambas as referencias coronímicas. En efecto, o adverbio "pariter" e a conxunción copulativa " $e t$ " diferéncianas dun xeito nidio; e o seu emprego deviría en improcedente en caso de se situaren os Auregensium loca na contorna do Valadouro, a priori "dentro", e non "á parte", dos Lucensis conuentus maritima loca. Ademais, o adxectivo "uicina", que concerta coas dúas referencias coronímicas, evidencia a veciñanza destas co propio Recimundo, caudillo suevo lucense, e non necesariamente entre elas. Como argumento externo á referencia hidaciana, cómpre engadirmos que o topónimo medieval Aurium, de orixe hidronímica e conservado no actual "Valadouro", non atoparía unha derivación lingüisticamente canónica nun etnónimo "Auregenses", senón, do mesmo xeito ca Auria-Ourense, nun *Aurienses. Semellante atranco da derivación lingüística non se repetiría nas dúas hipotéticas reducións específicas fornecidas, Aurega e Oulego, cuxos etnónimos latinos derivados si serían invariabelmente "Auregenses".

Considerando, pois, uns meirandes atrancos para a redución setentrional dos Auregenses, cumpriría valorarmos preferentemente as opcións da contorna de Ourense e o Macizo Galaico, ou a de Tui e o río Limia; localizacións nas que atopariamos o límite meridional da influencia da facción setentrional sueva. A significancia histórica destes lindeiros é decisiva: por primeira vez, e encadrelando cos synodi do século seguinte, enxergamos a contorna de Ourense, ou a de Tui, vencellada ao ámbito setentrional-lucense, e non ao meridional-bracarense. Neste senso, que a dependencia da contorna de Ourense e/ou Tui verbo a Lugo, innovación rastrexábel nas faccións suevas, se repita nos synodi, conforma un indicio ineludíbel da relación xenealóxica entrambos os ordenamentos territoriais. Semella poder confirmarse, xa que logo, a segunda hipótese de Demetrio Mansilla Reoyo ${ }^{131}$.

O principal atranco para a confirmación desta hipótese é a distancia cronolóxica entrambos os ordenamentos territoriais, como xa se ten observado ${ }^{132}$ : máis dun século separa, en efecto, o remate das faccións suevas no 464, do testemuño dos synodi no 572. Porén, o certo é que a isto se suma a completa escuridade que arrodea tal intervalo: de feito, a historiografía denomínao ilustrativamente "século" ou "período escuro" suevo. Como xa se mencionou, Remismundo, caudillo suevo setentrional, imporíase como único rei suevo no 464. Pero no 468 interrómpese

131 D. Mansilla Reoyo, Orígenes..., páx. 278; véxase arriba $§ 6$.

132 P. Ubric Rabaneda, La Iglesia..., páx. 322. 
o Cronicón de Hidacio de Chaves, o que determina o case nulo rexistro histórico dende este intre ata a segunda e definitiva conversión sueva ao catolicismo a mediados do século VI, e concretamente, como documento específico, as actas do primeiro concilio de Braga do 561. Ou sexa, que o ordenamento político da Gallaecia sueva fica ignoto entre o 468 e o 561.

A isto engádese que a dinámica histórica do período de asentamento suevo testemuñado (409/411-468) foi tremendamente inestábel ${ }^{133}$, alternándose fases relativamente breves de consolidación e descomposición política. Descoñecemos se este patrón de inestabilidade mantería a súa incidencia durante o século escu$r^{134}$, e nomeadamente se se volvería reproducir dun xeito intermitente a mesma dicotomía política que emerxera coas faccións suevas. Neste senso, é ineludíbel o serodio -alto-medieval-Cronicón Iriense, que asocia directamente a consolidación política suevo-católica á imposición dun rei suevo-lucense sobre outro bracaren$\mathrm{se}^{135}$. Embora se presuma a fantasiosidade deste reporte cronístico ${ }^{136}$, o certo é que o escaso rexistro histórico non autoriza nin a obstarmos nin a verificarmos dun xeito unívoco o episodio que relata; e moito menos a reprodución intermitente durante o século escuro da dicotomía territorial galaico-sueva manifestada puntualmente nas faccións.

Voltando á cuestión eclesiástica, engádese que nin sequera na segunda metade do século $\mathrm{V}$ estaba aínda consolidada a primacía metropolitana de Braga no ámbito galaico, e que as primeiras referencias explícitas da mesma se adían ata a década do $530^{137}$. Así como o Reino Suevo conformara unha unidade coherente antes da súa derrota militar do 465 fronte aos visigodos, a Igrexa galaica, allea á coxuntura política, ficara atomizada entre as súas diversas comunidades locais, antes e despois do colapso do Reino. As faccións, dada a súa querela pola dignidade rexia ${ }^{138}$, aspiraron dende o seu xurdimento á reunificación dos suevos, o que a priori desbota que pretendesen conscientemente a territorialización dos seus respectivos e parciais dominios políticos. Ademais, o arianismo debeu de ter unha significativa incidencia en ambas as faccións, e dende logo na triunfante. Nestas circunstancias, non semella razoábel que o embrionario poder suevo-ariano cominase ou determinase á Igrexa galaica a se adaptar ao seu novo e volúbel ordenamento político. Se cadra foi a propia disgregación eclesiástica, condicionada

\footnotetext{
${ }^{133}$ Ibíd., páxs. 108 e seguintes; M. Fernández CALo, A organización..., páxs. 93-97.

${ }^{134}$ M. Fernández Calo, A organización..., páx. 97.

${ }^{135}$ Chronicon Iriensis, 1.

${ }^{136}$ Manuel Rubén García Álvarez, "El Cronicón Iriense: estudio preliminar, edición crítica y notas históricas”, Memorial Histórico Español, 50 (1963), páxs. 131-134; A. López Carreira, O reino..., páx. 66.

${ }^{137}$ D. Mansilla Reoyo, Orígenes..., páxs. 275-281; P. Ubric Rabaneda, La Iglesia ..., páxs. 315-323. ${ }^{138}$ Hyd., Chron., 181 [188].
} 
pola análoga inestabilidade política, a que determinou, durante o século escuro, a conformación de dous ámbitos de influencia na Igrexa galaica, centrados respectivamente en Braga e Lugo, e correspondentes á dicotomía política emerxida nas faccións suevas; da que asemade ignoramos a súa reprodución intermitente a posteriori. Neste senso, a bipartición metropolitana da Igrexa galaica non pode ser separada do propio desenvolvemento do artellamento metropolitano. Se a consolidación metropolitana de Braga só é retrotraíbel con seguridade ao século VI, semella razoábel que nas mesmas datas xurdisen disensións noutras igrexas galaicas que anteriormente mantiveran a súa autonomía, empecendo tal consolidación metropolitana e motivando finalmente a bipartición da provincia eclesiástica.

En suma, a dicotomía política sueva do "período de faccións" supón un nidio antecedente xurisdicional da senlla bipartición metropolitana que os synodi sancionarían no século seguinte. A territorialidade, análoga entrambos os casos, difire asemade da administración romana previa e da visigoda posterior. É, pois, improbábel que a territorialidade coincidente entre as faccións e os synodi sexa casual. Isto, finalmente, apoia a hipótese da relación xenealóxica entrambas as demarcacións, se é que os synodi sancionaron a nivel eclesiástico a diverxencia política, se cadra reproducida intermitentemente durante o século escuro, entre os ámbitos setentrional e meridional do dominio suevo da Gallaecia.

\section{CONCLUSIÓNS}

Os resultados obtidos no presente estudo non son indefectibelmente concluíntes. Amosouse, con todo, en base ao contexto eclesiástico global, que de certo existe un factor político detrás da instauración dos synodi suevo-católicos na Gallaecia. Tal factor, ora por eludilo, ora por marxinalo, non foi debidamente valorado pola historiografía. Malia analizarmos en fondura aquí este mesmo factor político, non foi posíbel concretalo dun xeito seguro. Con todo, si é posíbel enunciarmos como achegas do presente estudo as seguintes proposicións:

$1^{\mathrm{a}}$.- Os synodi de Braga e Lugo dividiron a potestas e a xurisdición metropolitana da Igrexa galaica durante o derradeiro lapso do período suevo-católico.

$2^{\mathrm{a}}$-- As modificacións da territorialidade metropolitana da Igrexa tardo-antiga non se deben unicamente á dinámica propiamente eclesiástica, senón que, de feito, adoitan ter como factor principal o poder temporal.

$3^{\mathrm{a}}$-- Como factor político da promoción específica da igrexa de Lugo, testemúñase o asentamento da monarquía sueva nesta cidade dende a imposición do caudillo Remismundo no 464, ata unha data dende logo posterior, embora indeterminada. 
4a .- Do mesmo xeito, como factor político da bipartición metropolitana da Igrexa galaica, testemúñanse as faccións que dividiron e enfrontaron as áreas meridional e setentrional do asentamento suevo entre o 456 e o 464.

5a.- A relación xenealóxica entre os synodi do século VI e as faccións suevas do $\mathrm{V}$ apóiase na inserción en ambos os casos da contorna de Ourense e/ou Tui dentro do ámbito setentrional-lucense, singularidade entre a dependencia meridional-bracarense previa destes dous espazos en época romana e a desaparición posterior da dicotomía administrativa galaica en época visigoda. Neste senso, a herdanza directa explicaría que a territorialidade eclesiástica da Gallaecia do século VI reproduza a dicotomía política sueva do V.

6a .- Atópase, como atranco para a verificación ou refutación desta hipótese, o século escuro suevo, que impide confrontar durante o seu amplo lapso (ca. 468-561) o papel político de Lugo e a incidencia da dicotomía territorial da Gallaecia sueva.

\section{BIBLIOGRAFÍA}

Aja Sánchez, José Ramón, "Innovaciones bajo-imperiales en el modelo de urbs: el obispo cristiano y su influjo en la organización urbana”, en Antonio Rodríguez Colmenero, Los orígenes de la ciudad en el noroeste hispánico, t. II, Lugo, Deputación Provincial de Lugo, 1998, páxs. 1367-1374.

Alarcão, Jorge de, "Os limites das dioceses suevas de Bracara e de Portucale", Portugalia, 36 (2015), páxs. 35-48.

Alföldy, Géza, Provincia Hispania Superior, A Coruña, Universidade da Coruña, 2002.

Arias Vilas, Felipe, "A transición do mundo galaico-romano ó reino dos suevos", en José Manuel García Iglesias et al., Galicia Castrexa e Romana: Galicia Castreña y Romana, Lugo, Xunta de Galicia, 1997, páxs. 289-297.

Barbero, Abilio, "Las divisiones eclesiásticas y las relaciones entre la iglesia y el Estado en la España de los siglos VI y VII", en Abilio Barbero, La sociedad visigoda y su entorno histórico, Madrid, Siglo XXI, 1992, páxs. 168-198.

Barroso Cabrera, Rafael, Morín de Pablos, Jorge e Sánchez Ramos, Isabel, “Gallaecia Gothica: de la conspiración del Dux Argimundus (589/590 d.C.) a la integración en el Reino visigodo de Toledo", Idanha-a-Velha, 1 (2015), páxs. 1-156.

Beltrán Torreira, Federico Mario, "El conflicto por la primacía eclesiástica de la Cartaginense y el III Concilio de Toledo", en Concilio III de Toledo: XIV centenario: 589-1989, 1991, Toledo, Arzobispado de Toledo, páxs. 497-510.

Berend, Nora, Urbańczyk, Przemysław e Wiszewski, Przemysław, Central Europe in the High Middle Ages: Bohemia, Hungary and Poland, c. 900-c. 1300, Cambridge, Cambridge University Press, 2013. 
Birley, Anthony R., The Roman Government of Britain, Oxford, Oxford University Press, 2005. Bravo Castañeda, Gonzalo, Diocleciano y las reformas administrativas del Imperio, Madrid, Akal, 1991.

Candelas Colodrón, César, "Plebs y aristocracia en el cronicón de Hidacio: la organización política hispanorromana en el siglo V", Polis, 13 (2001), páxs. 129-139.

Cañizares del Rey, Buenaventura, “Concilios Lucenses”, Lucensia, 34 (2007), páxs. 173-190.

Carbajal Sobral, José, Los concilios de Braga en los siglos VI y VII, reflejo de la vida en la Gallaecia de la época, Porriño, 1999.

Chastagnol, André, La fin du monde antique: de Stilicon à Justinien (Ve siècle et début VIe), Paris, Nouvelles Editions Latines, 1976.

Costa, Avelino de Jesus da, O bispo D. Pedro e a organização da arquidiocese de Braga, vol. I, Braga, Irmandade de S. Bento da Porta Aberta, 1999.

David, Pierre, Études historiques sur la Galice et le Portugal du VI a au XII siècle, Lisboa-Paris, Portugalia-Les Belles Lettres, 1947.

David, Pierre, La métropole ecclésiastique de Galice du VIII a a XI siècle, Coimbra, Universidade de Coimbra-Instituto de Estudos Históricos Doutor António de Vasconcelos, 1947.

Díaz, Manuel Cecilio, "La cristianización en Galicia", en Fernando Acuña Castroviejo et al., La romanización de Galicia, A Coruña, Castro, 1976, páxs. 105-120.

Díaz, Manuel Cecilio e Vilariño Pintos, Daría, "La diócesis de Tuy hasta 1100”, en García Oro, José (coord.), Historia de las Diócesis Españolas, t. XIV, Madrid, Biblioteca de autores cristianos, 2002, páxs. 538-548.

Díaz Martínez, Pablo de la Cruz, "Gallaecia: de Reino Suevo a provincia visigoda", en Gerardo Pereira Menaut, Galicia fai dous mil anos: o feito diferencial galego, vol. I, Santiago de Compostela, Museo do Pobo Galego, 1997, páxs. 253-278.

Díaz Martínez, Pablo de la Cruz, "El Parrochiale Suevum: organización eclesiástica, poder político y poblamiento en la Gallaecia Tardoantigua", en Jaime Alvar, Homenaje a José María Blázquez, vol. VI, Sevilla, Ediciones Clásicas, 1998, páxs. 35-47.

Díaz Martínez, Pablo de la Cruz, “La Hispania Visigoda (257-611)”, en Pablo de la Cruz Díaz Martínez, Celia Martínez Maza e Francisco Javier Sanz Huesma, Hispania tardoantigua $y$ visigoda, Madrid, Istmo, 2007, páxs. 257-612.

Díaz Martínez, Pablo de la Cruz, El reino suevo: 411-585, Madrid, Akal, 2011.

Domínguez Monedero, Adolfo Jerónimo, "La Chronica Caesaraugustana y la presunta penetración popular visigoda en Hispania”, Antigüedad y cristianismo, 3 (1986), páxs. 61-68.

Dunn, Marilyn, The Christianization of the Anglo-Saxons, c.597-c.700: Discourses of Life, Death and Afterlife, London-New York, Continuum, 2010.

Escalona Monge, Julio, "Patrones de fragmentación territorial: el fin del mundo romano en la Meseta del Duero", en Urbano Espinosa Ruíz e Santiago Castellanos García (eds.), Comunidades locales y dinámicas de poder en el norte de la Península Ibérica durante la Antigüedad Tardía, Logroño, Universidad de La Rioja, 2006, páxs. 165-199.

Fernández Calo, Martín, A organización político-administrativa de Galicia na Antigüidade: séculos II a.C. - VIII d.C., Santiago de Compostela, Universidade de Santiago de Compostela (tese de licenciatura), 2015. 
Fernández Calo, Martín "Plinio, o Parroquial Suevo, e a evolución estrutural do poder local galaico na Antigüidade", en prensa.

Ferrando y Arnau, Francisco María, Un concilio celebrado en Lugo el año 569: estudio histórico, Lugo, Juan María Bravo, 1893.

Flórez, Enrique, España Sagrada, t. XXII, Madrid, Viuda e hijo Marín, 1798.

Flórez, Enrique, España Sagrada, t. IV, Madrid, Real Academia de la Historia, 1839.

Gaddis, Michael, "The Political Church: Religion and the State", en Philip Rousseau, A Companion to Late Antiquity, Chichester, Blackwell, 2014, páxs. 512-524.

García Álvarez, Manuel Rubén, “El Cronicón Iriense: estudio preliminar, edición crítica y notas históricas”, Memorial Histórico Español, 50 (1963), páxs. 131-134.

García Moreno, Luis A., "La Iglesia y el cristianismo en la Galecia de época sueva”, Antigüedad y cristianismo, 23 (2006), páxs. 39-55.

García Moreno, Luis A., Leovigildo: unidad y diversidad de un reinado, Madrid, Real Academia de la Historia, 2008.

García Villada, Zacarías, Historia Eclesiástica de España, t. II, $1^{\text {a }}$ parte, Madrid, Razón y Fe, 1932.

González Blanco, Antonino, "El decreto de Gundemaro y la historia del siglo VII”, Antigüedad y cristianismo, 3 (1986), páxs. 159-170.

Heather, Peter, "State, Lordship and Community in the West (c. A.D. 400-600)", en Averil Cameron, Bryan Ward-Perkins e Michel Whitby, The Cambridge Ancient History, t. XIV, Cambridge, Cambridge University Press, 2007, páxs. 437-468.

Isla Frez, Amancio, La sociedad gallega en la Alta Edad Media, Madrid, Centro Superior de Investigaciones Científicas, 1992.

Jeangène Vilmer, Jean-Baptiste, "Commentaire du Concordat de 1801 entre la France et le Saint-Siège", Revue d'Histoire Ecclésiastique, 102, 1 (2007), páxs. 124-154.

Liebeschuetz, John Hugo Wolfgang Gideon, "Administration and Politics in the Cities of the Fifth to the mid Seventh Century", en Averil Cameron, Bryan Ward-Perkins e Michel Whitby, The Cambridge Ancient History, t. XIV, Cambridge, Cambridge University Press, 2007, páxs. 207-237.

López Alsina, Fernando, La ciudad de Santiago de Compostela en la Alta Edad Media, Santiago de Compostela, Ayuntamiento de Santiago de Compostela, 1988.

López Carreira, Anselmo, O reino medieval de Galicia: contribución a unha historia política, Vigo, A Nosa Terra, 2008.

López Quiroga, Jorge, El final de la Antigüedad en la Gallaecia: la transformación de las estructuras de poblamiento entre Miño y Duero, siglos V al X, A Coruña, Pedro Barrié de la Maza, 2004.

López Quiroga, Jorge e Rodríguez Lovelle, Mónica, "El problema del limes de época visigoda en Galicia: nuevas consideraciones a partir de una relectura de las fuentes escritas y arqueológicas”, Guimarães, 104 (1994), páxs. 83-107.

López Quiroga, Jorge e Rodríguez Lovelle, Mónica, “De los Vándalos a los Suevos en Galicia: una visión crítica sobre su instalación y organización territorial en el noroeste de la Península Ibérica en el siglo V”, Studia Historica, 13-14 (1995-1996), páxs. 421-436. 
López Sangil, José Luis e Vidán Torreira, Manuel, "El Tumbo Viejo de Lugo (Transcripción Completa)", Estudios Mindonienses, 27 (2011), páxs. 11-373.

López Silva, José Antonio, A Crónica de Idacio de Limia, bispo de Chaves, Ourense, Deputación Provincial, 2004.

Macías, Marcelo, Cronicón de Idacio: versión castellana, con abundantes notas y aclaraciones, precedida de un estudio del insigne obispo y su obra, Ourense, 1906.

Mansilla Reoyo, Demetrio, "Orígenes de la organización metropolitana en la Iglesia española", Hispania Sacra, 12 (1959), páxs. 255-290.

Mathisen, Ralph W., "The Council of Turin (398/399) and the Reorganization of Gaul ca. 395/406", Journal of Late Antiquity, 6, 2 (2014), páxs. 264-307.

Novo Güisán, José Miguel, "Lugo en los tiempos oscuros: las menciones literarias de la ciudad entre los siglos V y X (3)”, Boletín do museo provincial de Lugo, 8, 2 (1997-1998), páxs. 177-194.

Novo Güisán, José Miguel, "Lugo nos tempos escuros: as mencións literarias da cidade entre os séculos V e X (9)”, Boletín do Museo Provincial de Lugo, 13 (2006-2008), páxs. 205-208.

Núñez García, Óscar, Un novo deus para os galaicos: a cristianización de Gallaecia, Santiago de Compostela, Lóstrego, 2012.

Núñez García, Óscar, "Cristianismo, sociedad y poder: origen y evolución de la jerarquía eclesiástica en la Gallaecia antigua”, Hispania Sacra, LXV, extra 2 (2013), páxs. 7-31.

Orlandis Rovira, José, "Las relaciones intereclesiales de la Hispania visigótica", Communio, 12 (1972), páxs. 403-444.

Ozcáriz Gil, Pablo, Los conventus de la Hispania Citerior, Madrid, Universidad Rey Juan Carlos, 2006.

Ozcáriz Gil, Pablo, "Algunas consideraciones acerca de la provincia Hispania Superior y su administración”, Pyrenae, 38, 2 (2007), páxs. 33-46.

Pérez Martínez, Meritxell, "La burocracia episcopal en la Hispania Tardorromana y visigótica (siglos IV y VII)”, Studia Historica, 18-19 (2000-2001), páxs. 17-40.

Potter, David S., "The Transformation of the Empire: 253-337 CE", en David S. Potter, The Blackwell Companion to the Roman Empire, Malden-Oxford-Carlton, Blackwell, 2006, páxs. 153-173.

Presedo Velo, Francisco J., La España Bizantina, Sevilla, Universidad de Sevilla, 2003.

Rivas Fernández, Juan Carlos, Antigüedad del episcopado auriense, Ourense, Duen de Bux, 2003.

Sánchez Pardo, José Carlos, "Organización eclesiástica y social en la Galicia tardoantigua: una perspectiva geográfico-arqueológica del Parroquial Suevo", Hispania Sacra, LXVI, 134 (2014), páxs. 439-480.

Sanz Huesma, Francisco Javier, "Historia política”, en Pablo de la Cruz Díaz Martínez, Celia Martínez Maza e Francisco Javier Sanz Huesma, Hispania tardoantigua y visigoda, Madrid, Istmo, 2007, páxs. 25-86.

Soares, Franquelim Neiva, “Os Concílios Suevos de Braga (561 e 572)”, páxs. 74-75, en Erwin Koller e Hugo Laitenberger (eds.), Suevos-Schwaben: das Königreich der Sueben auf der Iberischen Halbinsel, 411-585, Tübingen, Gunter Narr Verlag, 1998, páxs. 63-79. 
Sotomayor y Muro, Manuel, "La Iglesia de la España romana”, en Ricardo García Villoslada, Historia de la Iglesia en España, t. I, Madrid, La Editorial Católica, 1979, páxs. 7-400.

Thompson, Edward Arthur, Romans and Barbarians: The Decline and Fall of the Western Empire, Madison, University of Wisconsin Press, 1982.

Torres Rodríguez, Casimiro, El reino de los suevos, A Coruña, Barrié de la Maza, 1977.

Tranoy, Alain, La Galice Romaine: recherches sur le nord-ouest de la péninsule ibérique dans l'Antiquité, Paris, Diffusion de Boccard, 1981.

Ubric Rabaneda, Purificación, La Iglesia y los Estados bárbaros en la Hispania del siglo V: 409-507, Universidad de Granada (tese de doutoramento), 2003.

Vilella Masana, Josep, "Los concilios eclesiásticos hispanos del período visigodo-arriano: análisis histórico-prosopográfico", Medieval Prosopography, 25 (2008), páxs. 1-47.

Ward-Perkins, Bryan, “The Cities”, en Averil Cameron e Peter Garnsey, P. (eds), The Cambridge Ancient History, t. XIII, Cambridge, Cambridge University Press, 1998, páxs. 337-425.

Wickham, Chris, Framing the Early Middle Ages: Europe and the Mediterranean, 400-800, Oxford, Oxford University Press, 2005.

Wood, Ian, The Merovingian Kingdoms, 450-751, London-New York, Routledge, 2014.

Yorke, Barbara, The Conversion of Britain: Religion, Politics and Society in Britain, c.600-800, London-New York, Routledge, 2014.

Young, Simon, Britonia: camiños novos, Noia, Toxosoutos, 2002. 